\title{
Suction effects on a compacted clay under non-isothermal conditions
}

\author{
E. ROMERO, ${ }^{*}$ A. GENS ${ }^{*}$ and A. LLORET*
}

The paper presents the results of an experimental study on the effects of suction and temperature on the volumetric behaviour of an unsaturated soil. Statically compacted Boom clay samples have been used in the testing programme, which has been performed using an oedometer apparatus with simultaneous control of suction and temperature. Suctions up to 0.45 MPa and temperatures up to $80^{\circ} \mathrm{C}$ have been applied. Special measures have been taken to control and minimise the problems associated with phase changes and vapour migration at high temperatures. A comprehensive experimental programme has been carried out, including isothermal tests with control of vertical stress, suction and temperature, non-isothermal tests under constant suction, and isothermal swelling pressure tests. Testing samples at two compacted soil densities provides observations concerning a wide scope of behaviour ranging from collapse to swelling behaviour on wetting. Test results obtained at $80^{\circ} \mathrm{C}$ have been compared with those of tests performed at room temperature $\left(22^{\circ} \mathrm{C}\right)$. Based on these comparisons, thermal effects on a variety of features of behaviour such as swelling potential, swelling pressure, collapsibility, shrinkage strains, compressibility, stress path dependence and degree of strain reversibility are presented and discussed. Although the basic behaviour is similar at high and low temperatures, various significant differences are identified concerning mainly swelling strains developed during wetting and compressibility with respect to loading. Swelling pressure test results indicate that the high-temperature samples yield at a lower stress than that observed in room-temperature samples, suggesting that the stress domain bounded by the main yield surface reduces as temperature increases - a behaviour feature shared with saturated soils.

KEYWORDS: clays; laboratory tests; partial saturation; suction; temperature effects
Cet exposé présente les résultats d'une étude expérimentale sur les effets de la succion et de la température sur le comportement volumétrique d'un sol non saturé. Nous avons utilisé des échantillons d'argile de Boom, compactés de manière statique, dans un programme d'essais qui a été effectué en utilisant un odomètre avec commande simultanée de la succion et de la température. Des succions allant jusqu'à $0.45 \mathrm{MPa}$ et des températures allant jusqu'à $80^{\circ} \mathrm{C}$ ont été appliquées. Des mesures spéciales ont été prises afin de maîtriser et de minimiser les problèmes associés aux changements de phase et à la migration de vapeur à haute température.

Nous avons réalisé un programme complet d'expérimentation, comprenant des tests isothermes avec commande de la contrainte verticale, de la succion et de la température, des essais non isothermes sous succion constante et des essais de pression de gonflement isotherme. Les échantillons pour deux densités de sol compacté permettent d'observer une vaste gamme de comportements, allant de l'affaissement au gonflement lors de l'humidification. Nous avons comparé les résultats des essais à $80^{\circ} \mathrm{C}$ à ceux des essais à température ambiante $\left(22^{\circ} \mathrm{C}\right)$. En nous basant sur ces comparaisons, nous présentons et analysons les effets thermiques sur une variété de caractéristiques de comportement, comme le potentiel de gonflement, la pression de gonflement, la propension à l'effondrement, les déformations de retrait, la compressibilité, la dépendance vis-à-vis du chemin de contrainte et le degré de réversibilité de la déformation. Bien que le comportement de base soit similaire à haute et à basse température, nous identifions plusieurs différences significatives concernant principalement les déformations de gonflement qui apparaissent pendant l'humidification et la compressibilité par rapport à la charge. Les résultats des essais de pression de gonflement indiquent que les échantillons soumis à une haute température cèdent sous une contrainte plus faible que celle observée avec les échantillons à température ambiante, ce qui suggère que le domaine de contrainte limité par la principale surface d'écoulement baisse à mesure que la température augmente, comportement qui est partagé par les sols saturés.

\section{INTRODUCTION}

The extension of geotechnical engineering to new fields of application often requires the introduction of new variables for a more complete understanding of the behaviour of soil (Gens, 1997). A prominent example is the area of environmental geotechnics, where non-isothermal situations involving unsaturated materials are often encountered. In some cases, for instance in the storage and disposal of high-level nuclear waste, thermal effects can be dominant as quite high temperatures are reached in the engineered barriers placed

Manuscript received 7 May 2002; revised manuscript accepted 2 October 2002

Discussion on this paper closes 1 August 2003, for further details see p. ii.

* Universitat Politècnica de Catalunya, Barcelona, Spain. close to the waste (Gens et al., 1998; Kanno et al., 1999). Temperature is also relevant in other cases such as landfill liners, pavement-soil systems subjected to seasonal and daily cyclic seasonal changes, and in soils around buried high-voltage cables. Geotechnical applications to these new types of problem require the incorporation of new factors such as suction and temperature into current understanding of soil behaviour.

Thermal effects on saturated soils are a subject with a long research tradition (e.g. Campanella \& Mitchell, 1968; Baldi et al., 1988; Hueckel \& Baldi, 1990; Mitchell, 1993) that has recently attracted intense attention once again (Burghignoli et al., 2000; Delage et al., 2000; Graham et al., 2001). In contrast, available information concerning temperature effects on unsaturated soil is very limited in spite of its practical relevance - a situation caused, at least in part, by the difficulties in controlling water phase changes at high 
temperatures. Saix \& Jouanna (1990) and Saix (1991) reported the first experimental results in this area using extremely low suction values (less than $5 \mathrm{kPa}$ ). Recordon (1993) and Wiebe et al. (1998) studied the effects of thermal loading in partially saturated soils at constant water content - that is, without suction control. There is a need, therefore, to examine more systematically the combined effects of suction and temperature on the mechanical behaviour of unsaturated soils under more controlled conditions. Basic questions concerning the sensitivity to temperature of swelling potential and soil collapsibility, or the effects of temperature on the stress path dependence characteristics of soil deformation, remain largely unanswered. The need for an improved understanding of behaviour is especially important in the case of clay-rich compacted soils, often used in the construction of containment barriers. To achieve such an understanding it is necessary to perform tests under the simultaneous control of suction and temperature. A main challenge for such an undertaking is the devising of a reliable controlled-suction apparatus capable of working at elevated temperatures.

The paper contains the main results of a comprehensive laboratory investigation performed on a moderately swelling compacted clay to determine the combined effects of temperature and suction on its volume change characteristics. To the authors' knowledge, this is the first reported general study based on tests performed under simultaneous control of suction and temperature. Two different soil fabrics are studied: a loose one (dry unit weight $13.7 \mathrm{kN} / \mathrm{m}^{3}$ ) and a denser one (dry unit weight $16.7 \mathrm{kN} / \mathrm{m}^{3}$ ). Temperature effects are identified by comparing the results of tests performed at $80^{\circ} \mathrm{C}$ with the rosults of the same type of test carried out at room tenseratur

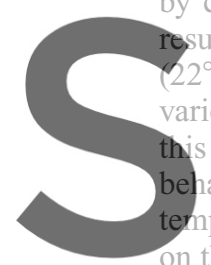
$\left.{ }^{\circ} \mathrm{C}\right)$. Some non-isothermal te aried during the test have also be s experimental study provide merature sol, in wh ch

the hydraulic properties of the elsewhere (Romero et al., 2000, 2001b). different dry unit weights were selected to achieve different types of unsaturated soil behaviour on wetting. At the stress levels used in the experimental programme, the loose samples generally develop compression (collapse) strains on wetting whereas the denser samples exhibit swelling strains during hydration. A summary of the as-compacted properties is listed in Table 1, where it can be observed that a slightly lower compaction vertical net stress is required to obtain a prescribed void ratio at higher temperatures.

The pore size distributions for the two values of dry density determined using mercury intrusion porosimetry on freezedried samples are presented in Fig. 1. The low-density sample displays an aggregated fabric and exhibits three peaks in the pore size distribution, defining pore size dominant modes at approximately $60 \mathrm{~nm}, 2 \cdot 1 \mu \mathrm{m}$ and $12 \mu \mathrm{m}$. The high-density sample shows a bimodal distribution with dominant pore sizes at $0.8 \mu \mathrm{m}$ and $21 \mathrm{~nm}$, indicating that changes in soil fabric caused by increasing compaction effort were mainly at the expense of the largest pore sizes between clay aggregates.

Figure 2 shows the main wetting branches of the water retention curves of the compacted samples, which were determined under constant void ratio and two different temperatures. Data points at high suctions $(s>3 \mathrm{MPa})$ were obtained from different samples using the vapour equilibrium technique, following a single-stage equalisation procedure starting from hygroscopic humidity (Romero et al. 2001b). Data points at low suctions $(s \leqslant 0.45 \mathrm{MPa})$ were determined using the axis-translation technique under constant-volume conditions. The samples were subjected to a multi-stage procedure: that is, the same sample underwent the various equalisation steps. The effect of temperature on

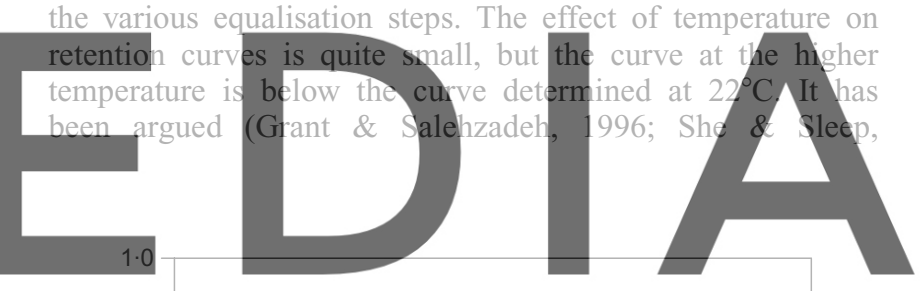

Register for free at https//www.scipedia.com to download the ver rs šlo ${ }^{3}$ without the watermark

SOIL PROPERTIES, EQUIPMENT AND EXPERIMENTAL PROCEDURES

\section{Material properties}

The material used for the tests was obtained by statically compacting natural Boom clay from Mol (Belgium) on the dry side. This moderately swelling clay $(20-30 \%$ kaolinite, $20-30 \%$ illite and $10-20 \%$ smectite) has a liquid limit, $w_{\mathrm{L}}=56 \%$, a plastic limit, $w_{\mathrm{P}}=29 \%$, a unit weight of the solids of $26.5 \mathrm{kN} / \mathrm{m}^{3}$ at $22^{\circ} \mathrm{C}$, and $50 \%$ of particles smaller than $2 \mu \mathrm{m}$.

Samples (50 $\mathrm{mm}$ diameter and $10 \mathrm{~mm}$ high) at a prescribed water content of $15.0 \%$ were prepared at two dry unit weights $\left(\gamma_{\mathrm{d}}=13.7\right.$ and $\left.16.7 \mathrm{kN} / \mathrm{m}^{3}\right)$ and at two different temperatures $\left(22^{\circ} \mathrm{C}\right.$ and $\left.80^{\circ} \mathrm{C}\right)$, by one-dimensional static compaction under isothermal and constant water content conditions. The two

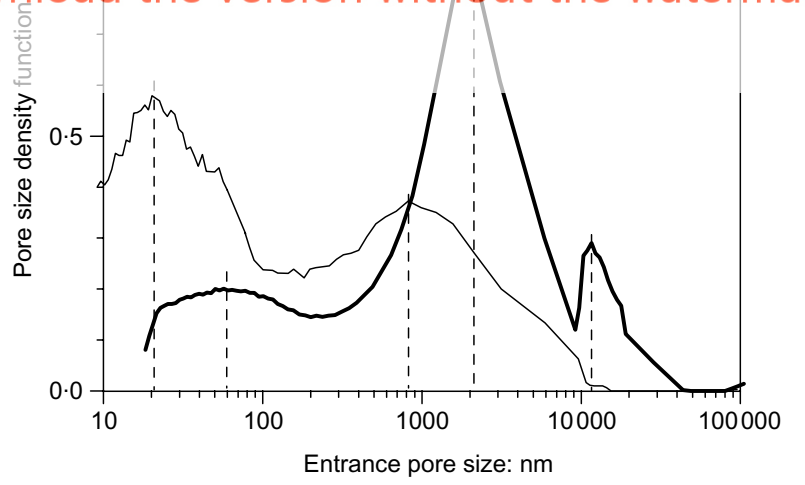

Fig. 1. Pore size distribution of Boom clay statically compacted to dry unit weights $13 \cdot 7$ and $16 \cdot 7 \mathrm{kN} / \mathrm{m}^{3}$

Table 1. As-compacted properties of the tested soil

\begin{tabular}{|c|c|c|c|c|c|}
\hline \multirow[t]{2}{*}{ Sample } & \multirow{2}{*}{$\begin{array}{l}\text { Void } \\
\text { ratio }\end{array}$} & \multirow{2}{*}{$\begin{array}{l}\text { Degree of } \\
\text { saturation }\end{array}$} & \multirow{2}{*}{$\begin{array}{l}\text { Approximate } \\
\text { suction†: MPa }\end{array}$} & \multicolumn{2}{|c|}{ Compaction net stress: $\mathrm{MPa}$} \\
\hline & & & & Vertical & Horizontal \\
\hline Low density & 0.932 & $0 \cdot 435$ & $\begin{array}{l}1.9 \text { at } 22^{\circ} \mathrm{C} \\
1.5 \text { at } 80^{\circ} \mathrm{C}\end{array}$ & $\begin{array}{l}1.27 \text { at } 22^{\circ} \mathrm{C} \\
1.18 \text { at } 80^{\circ} \mathrm{C}\end{array}$ & 0.47 at $22^{\circ} \mathrm{C}$ \\
\hline High density & 0.591 & $0 \cdot 687$ & $\begin{array}{l}1.9 \text { at } 22^{\circ} \mathrm{C} \\
1.5 \text { at } 80^{\circ} \mathrm{C}\end{array}$ & $\begin{array}{l}4.50 \text { at } 22^{\circ} \mathrm{C} \\
4.07 \text { at } 80^{\circ} \mathrm{C}\end{array}$ & 1.76 at $22^{\circ} \mathrm{C}$ \\
\hline
\end{tabular}

$\dagger$ See Fig. 2.

$\$$ Measured with compensated lateral stress ring at $22^{\circ} \mathrm{C}$. 

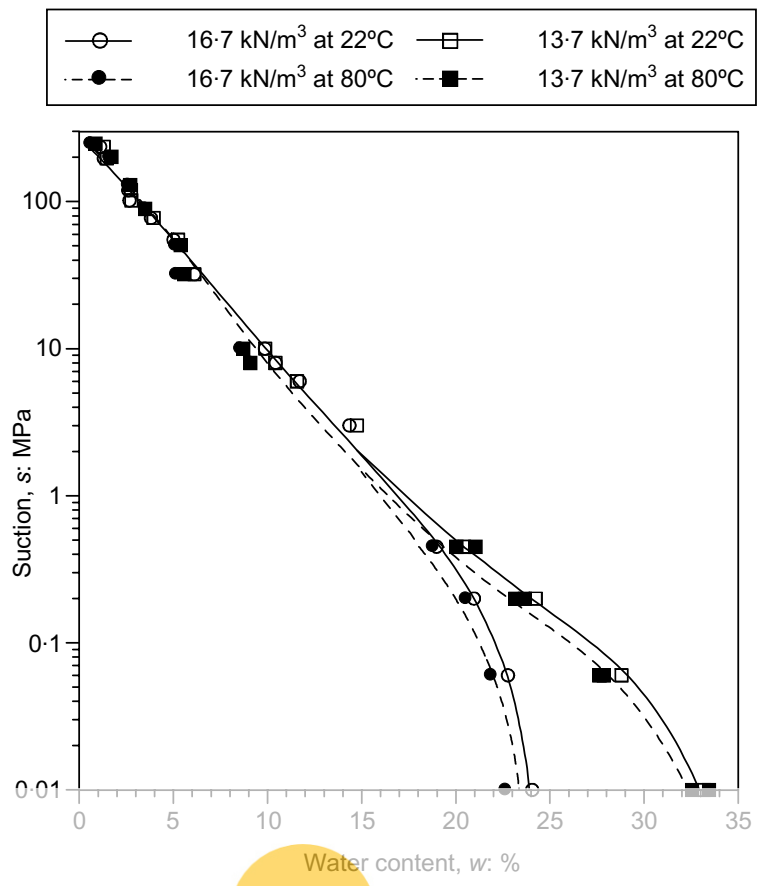

Fig. 2. Water retention curves for Boom clay compacted to dry unit weights 13.7 and $16.7 \mathrm{kN} / \mathrm{m}^{3}$ at two different temperatures. The retention curves have been determined during wetting under constant void ratio
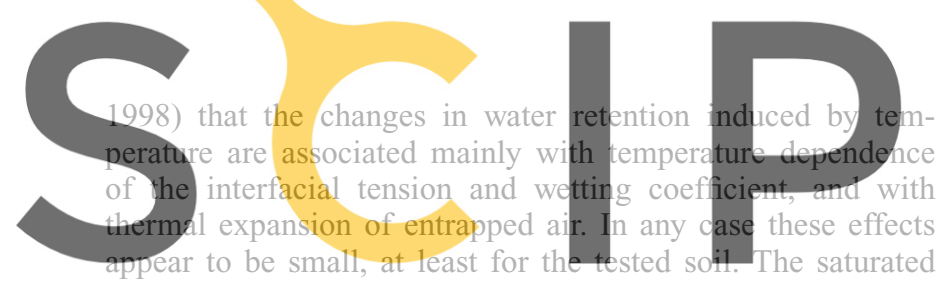

water content of the hotter samples is slightly less than that

Regisforter fool samples in site of having the fame dre density part, to the thermal expansion of water, since the variation of water density will imply that, for a given void ratio, the mass of water is smaller at higher temperatures. The effect of soil density on the retention curve disappears at water contents lower than $15 \%$, the fabrication water content.

\section{Equipment and experimental layout}

The tests have been performed in controlled-suction oedometer cells specifically designed for accurate temperature control. Fig. 3 shows the layout of the oedometer cell, the system for control of temperature and suction, and various auxiliary devices necessary to perform the tests. The oedometer ring was placed inside a silicone oil bath containing the heater in order to maintain thermal stability (heater and silicone oil bath are indicated by 1 in Fig. 3). The soil sample (2) is located between a high air-entry value (HAEV) ceramic disc at the bottom (3) and a coarse porous stone at the top (4). Soil temperatures were measured with a thermocouple located close to the sample, which was used as feedback signal acting on a programmable thermostat that controlled the heater. Another thermocouple recorded the temperature in the silicone oil bath. A water volume change indicator (resolution $25 \mathrm{~mm}^{3}$ ) connected to the HAEV ceramic disc and maintained at the reference laboratory temperature $\left(22 \pm 1^{\circ} \mathrm{C}\right)$ was used to measure the inflow and outflow of water. Additional details are given in Romero et al. (1995) and Romero (1999).

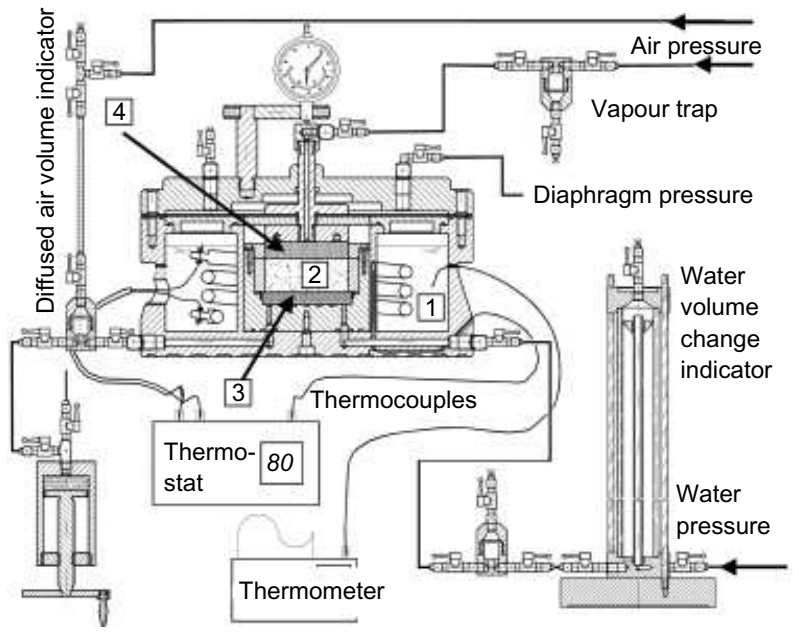

Fig. 3. Schematic layout of experimental system with simultaneous control of suction and temperature: 1 , silicone oil bath and heater; 2, soil sample; 3 , HAEV ceramic disc; 4 , coarse porous stone

Matric suction (denoted suction in the rest of the paper) was applied using the axis-translation technique. This procedure involved the application of an air pressure in which the soil is immersed to a constant value of $u_{\mathrm{a}}=0.5 \mathrm{MPa}$ that was 1S 1 maintained throughout the different testing paths. Syction
(the difference between air and water pore pressures,
$s=u_{\mathrm{a}}-u_{\mathrm{w}}$ ) was controlled by variable positive water pres-
sures. The air pressurisation was applied in the as-compacted
state at the degrces of saturation indicated in Table 1 to
ensure continuity of air and to minimise sofl skeleton
deformation due to pore furid compression, which may occur when occluded air bubbles are present. This technique has

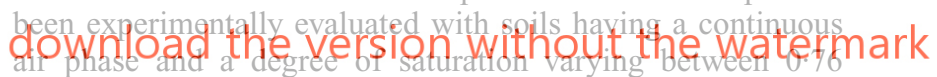
and 0.95 by Fredlund \& Morgenstern (1977). Some stages of the tests attained high degrees of saturation, in which the air phase would possibly be discontinuous. However, the soil response was continuous throughout and did not display any change in these stages that could indicate the technique was inadequate. Another significant limitation of this technique at high temperatures is that the system of air pressure application is not a closed system to vapour migration, which induces soil water to evaporate. Evaporation fluxes are generated owing to the difference in vapour pressure between the soil voids and the air pressure line going into the coarse porous stone. For this reason, a vapour trap was installed in the air pressure line to maintain a relative humidity higher than $98.5 \%$, which restricted vapour transfer and allowed suction equalisation over the entire sample height. Further details are discussed in Romero et al. (2001a, 2001b). An additional difficulty concerning the application of the axis-translation technique at high temperatures and suctions was associated with the accumulation of dissolved air beneath the HAEV ceramic disc, which could induce a progressive loss of continuity between pore water and the water in the measuring system. Therefore, as shown in Fig. 3, a diffused air volume indicator was incorporated in the water pressure system in order to periodically flush the dissolved air passing through the HAEV ceramic disc. This air volume was also measured throughout the test. With this experimental arrangement it was therefore possible to control and measure all fluid flows going into or out of the 
specimen. Using this equipment, generalised stress paths involving independent variations of vertical stress, suction and temperature can be applied.

\section{Experimental procedures}

Figure 4 shows the generalised stress paths followed in the experimental programme in a three-dimensional stresssuction-temperature space. Three types of test have been performed:

(a) isothermal tests with suction and stress control (path A)

(b) non-isothermal tests with suction and stress control (path B)

(c) isothermal wetting-drying tests under no volume change (isochoric) conditions (path $\mathrm{C}$ ).

The first series of tests were performed isothermally at $22^{\circ} \mathrm{C}$ and $80^{\circ} \mathrm{C}$ on low- and high-density samples. The stress paths on a constant temperature plane can be seen in Fig. 5(a). Samples were first loaded at constant water content, starting from the as-compacted state up to different target vertical net stresses $\left(\sigma_{\mathrm{v}}-u_{\mathrm{a}}\right)$ (path $\mathrm{AB}$ ): 0.026 , $0.085,0.30$ and $0.55 \mathrm{MPa}$ for the high-density soil, and $0.085,0.30,0.60$ and $1.20 \mathrm{MPa}$ for the low-density samples. Once the target net stress was reached, the sample was wetted and dried at constant stress following these suction steps (path BCDEF): 0.45, 0.20, 0.06 and 0.01 MPa. Equalisation stages lasted between nine and eleven days in the high-density samples and around six days in the low-density soils in order to achieve a volumetric strain rate of less than $0.025 \%$ /day at the end of the step. An equalisation cut-of criterion based
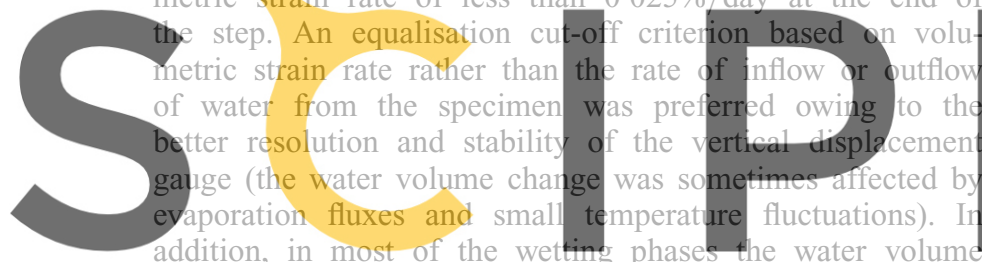

change (taking into consideration evaporative fluxes)

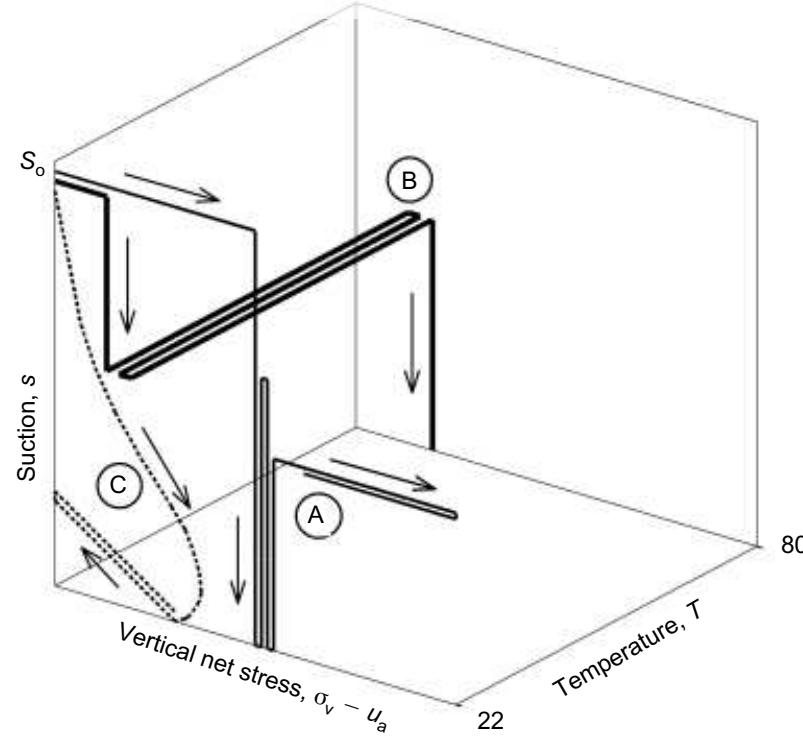

Fig. 4. Generalised stress paths used in the testing programme plotted in three-dimensional vertical net stress-suction-temperature space. Path $A$ : isothermal tests with suction and stress control. Path B: non-isothermal tests with suction and stress control. Path $C$ : isothermal wetting-drying tests under no volume change conditions stabilised first. Usually, in the wetting phases longer equalisation periods were required for the high-temperature tests, owing to some thermally enhanced creep observed in both swelling and collapse responses. As an illustrative example of the test observations obtained, Fig. 6 shows typical data for the time evolution of the volumetric strain and water content change during the wetting phases of the high-density sample at a constant vertical net stress of $\left(\sigma_{\mathrm{v}}-u_{\mathrm{a}}\right)=0.026 \mathrm{MPa}$ and at two different temperatures.

Test stages involving isothermal loading-unloading at constant suction were performed after the wetting-drying cycles. The stress paths are shown in Figs 5(c) and 5(d) for high- and low-density samples respectively. The load was applied in stages up to the maximum vertical stress indicated in the figures. Equalisation stages lasted three days in the high-density samples and two days in the low-density specimens so that the same volumetric strain rate at the end of the step as specified above was obtained. The same stress increment criterion and step loading duration were used at the two testing temperatures.

The tests involving drained heating and cooling paths (Fig. 5(b)) were performed on high-density samples that were brought to the desired suction along a wetting path Bc and then subjected to temperature cycles (path $\mathrm{c}-\mathrm{d}-\mathrm{e}-\mathrm{f}$ ) under constant suction and a constant stress $\left(\sigma_{\mathrm{v}}-u_{\mathrm{a}}\right)=$ 0.026 MPa. The following temperature steps were applied: $22,40,60$ and $80^{\circ} \mathrm{C}$. At every step, after a heating phase applied at a rate of $0 \cdot 16^{\circ} \mathrm{C} / \mathrm{min}$, temperature was maintained constant for nine to 15 days until reaching a volumetric strain rate of less than $0.025 \% /$ day. Cooling stages, applied at a rate of $-0.13^{\circ} \mathrm{C} / \mathrm{min}$, were maintained for three to five

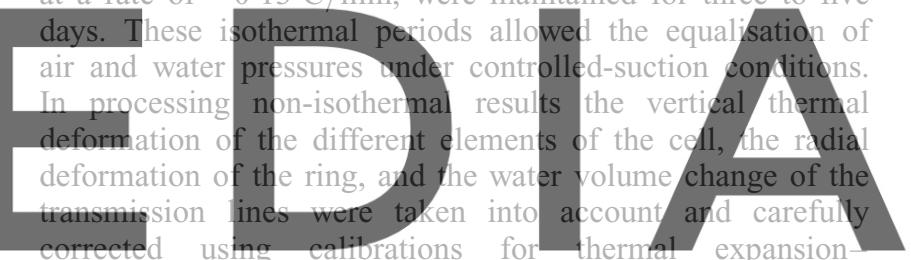

contraction obtained from repeated heating-cooling cycles

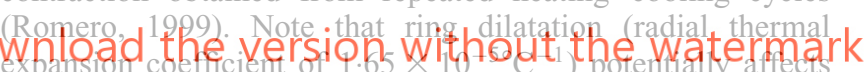
the oedometer's $K_{0}$ condition. However, thermal expansion and contraction of the oedometer ring is partially compensated for by the thermal strain of clay particles (volumetric thermal dilatation coefficient of $2.9 \times 10^{-5}{ }^{\circ} \mathrm{C}^{-1}$; Horseman \& McEwen, 1996) and is much smaller than the vertical strains measured in the tests on high-density samples. For this reason, it is believed that thermal deformations did not affect significantly the lateral strain of the specimens and, consequently, the volume change response of the soil. A similar conclusion was reached by Towhata et al. (1993, 1995), when performing non-isothermal consolidation tests on saturated clays.

For the constant-volume tests, the height of the samples was forced to remain constant during wetting and drying paths and the variation of the vertical net stress was recorded by means of an external load cell. The loading system compressibility in relation to the sample height was about $0.002 \mathrm{kN}^{-1}$. Wetting paths at the following suction steps were applied: $0.45,0.20,0.06$ and $0.01 \mathrm{MPa}$. After the wetting stage, suction was increased using the same steps to obtain the shrinkage curve under null volume change. This drying path was interrupted when shrinkage reached a stage at which the constant-volume condition could no longer be sustained. The equalisation stages were maintained for around three to five days until no more water content changes were recorded. These shorter equalisation periods allowed minimisation of some stress relaxation phenomena that were detected at higher temperatures. 

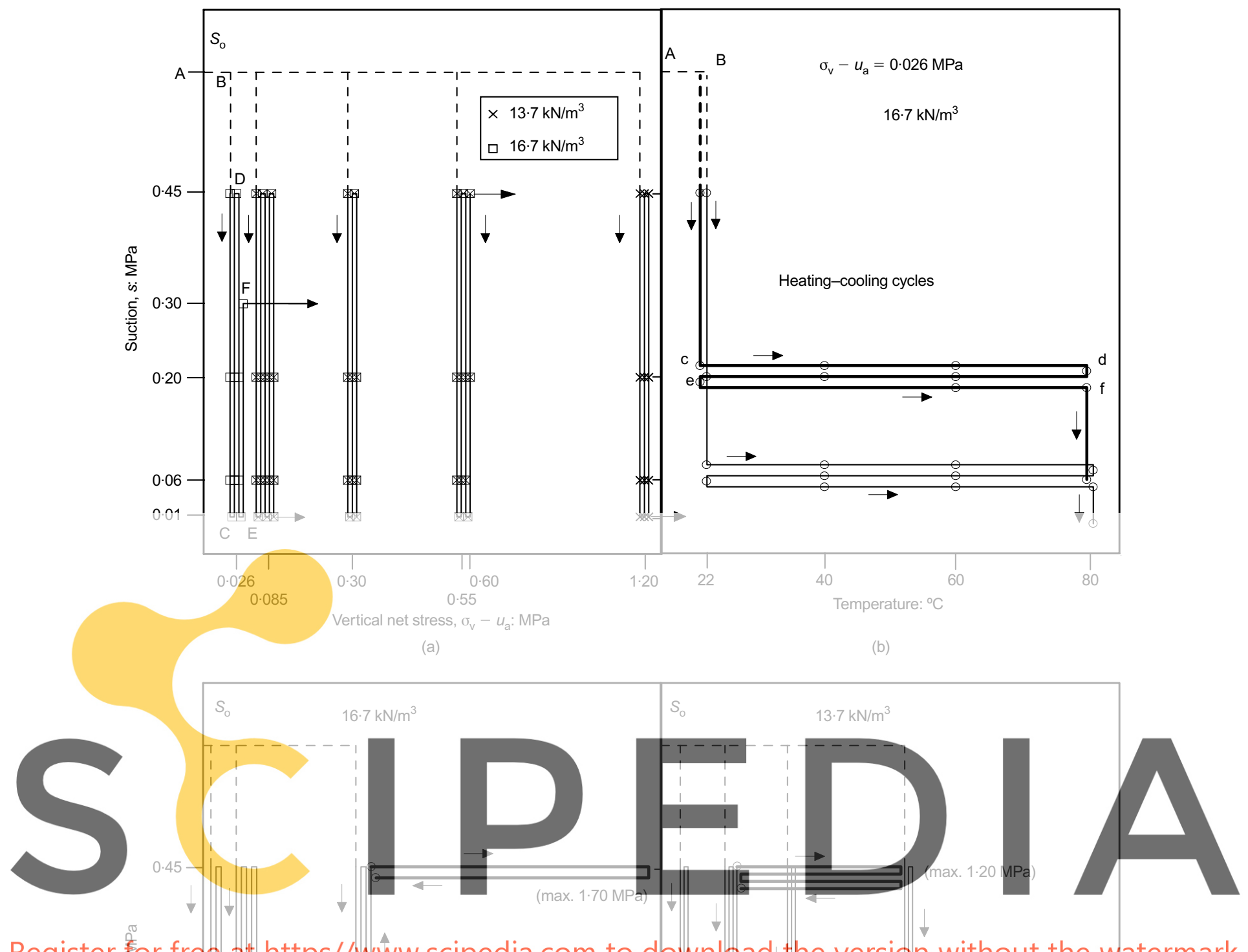

Register for free att https//WWWw.scipedia.com to download the version without the watermark

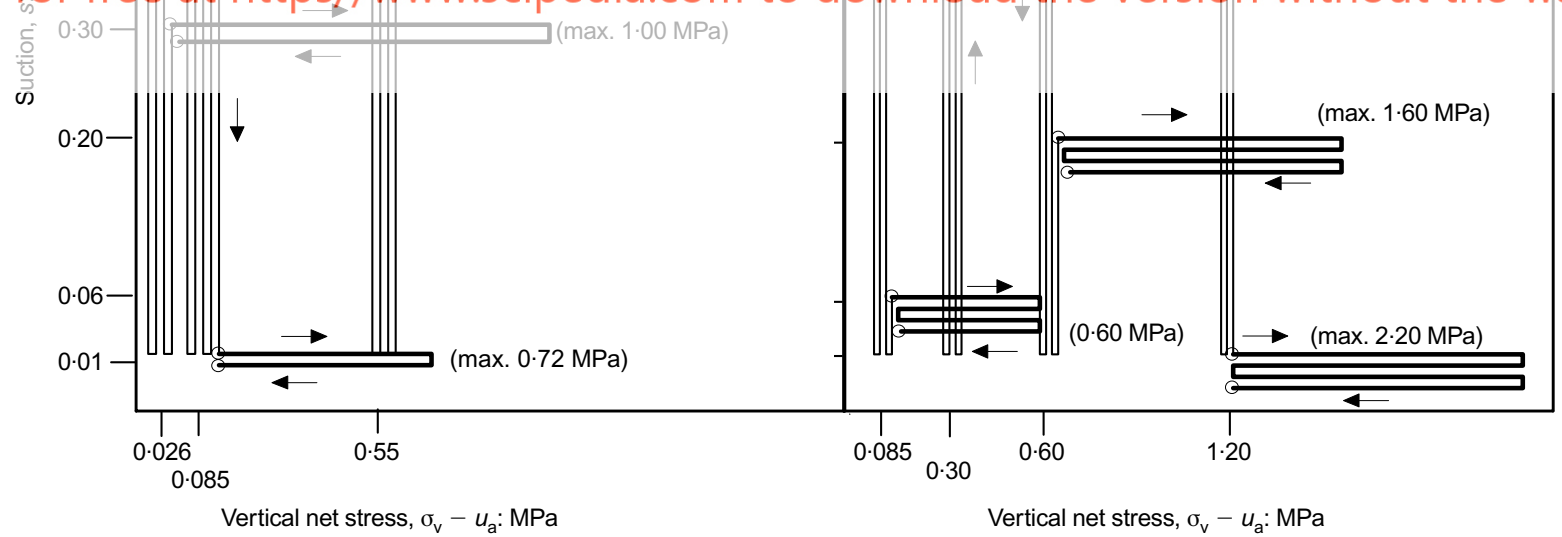

(c)

(d)

Fig. 5. Stress paths followed in: (a) isothermal wetting-drying cycles; (b) non-isothermal tests under constant vertical stress; (c), (d) isothermal loading-unloading tests on high-density $\left(\gamma_{d}=16 \cdot 7 \mathrm{kN} / \mathrm{m}^{3}\right)$ and low-density $\left(\gamma_{d}=13 \cdot 7 \mathrm{kN} / \mathrm{m}^{3}\right)$ samples respectively

\section{ANALYSIS OF THE EXPERIMENTAL RESULTS}

Isothermal wetting-drying under load tests (low- and highdensity samples)

In this section, the results of isothermal wetting-drying tests under constant applied load are discussed. The tests have been carried out at two different (constant) tempera- tures using low- and high-density samples. The results of subsequent loading-unloading stages of the same tests are examined in a later section.

Figure 6 shows the time evolution of volumetric strain and water content change for the wetting steps (path $\mathrm{BC}$ in Fig. 5(a)) of the high-density sample $\left(\gamma_{\mathrm{d}}=16 \cdot 7 \mathrm{kN} / \mathrm{m}^{3}\right)$ at 


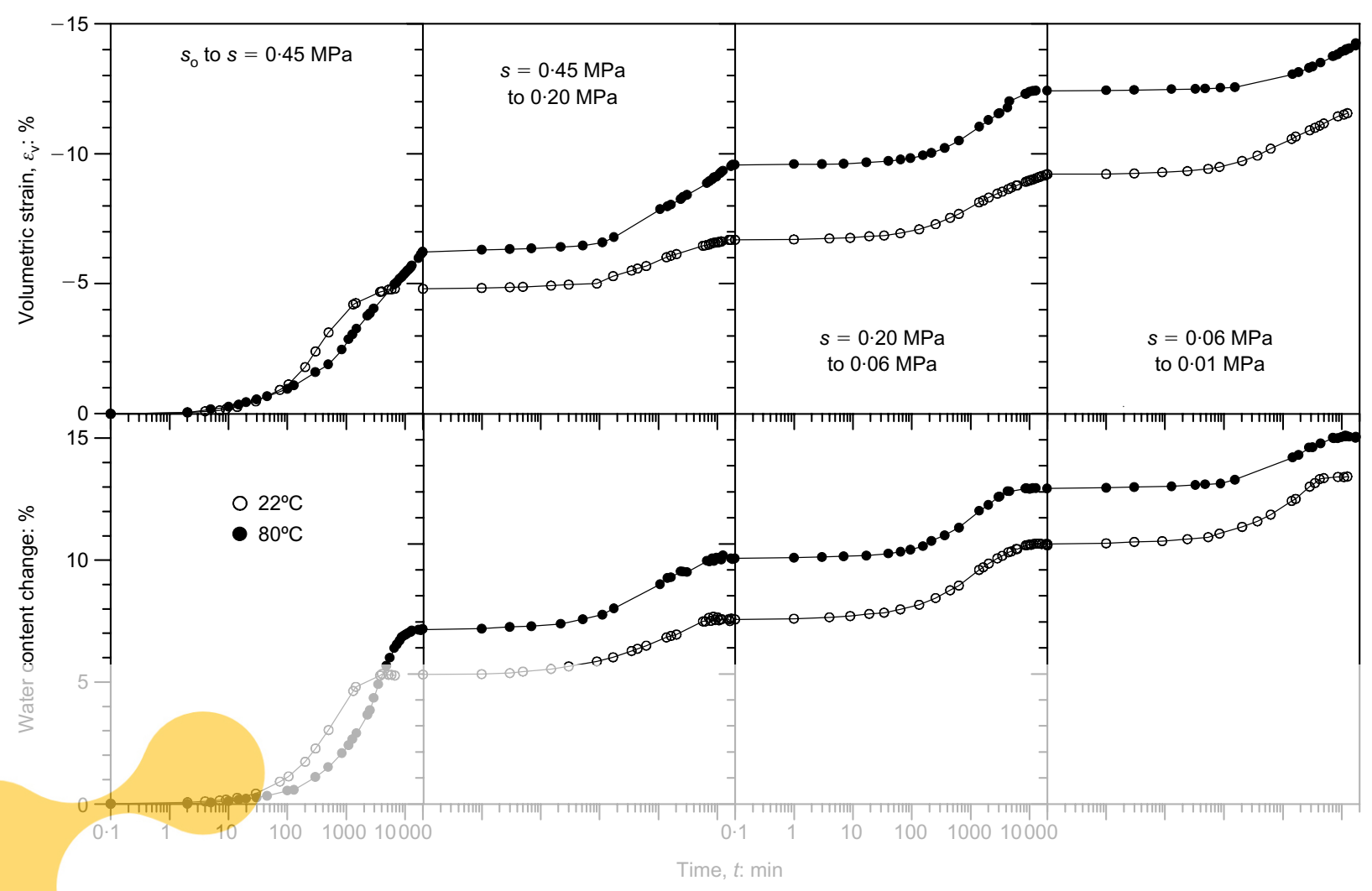

Fig. 6. Time evolution of volumetric strain and water content change in isothermal wetting path $\mathrm{BC}$ carried out on high-

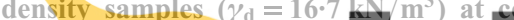

$\left.80^{\circ} \mathrm{C}\right)$

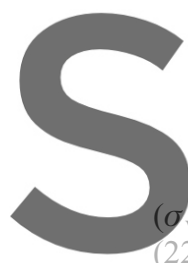

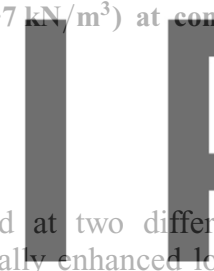

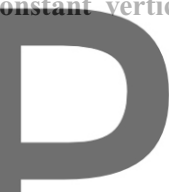

$\left.-u_{\mathrm{a}}\right)=0.026 \mathrm{MPa}$ and at two different temperature $\mathrm{C}$ and $80^{\circ} \mathrm{C}$ ). The thermally enhanced long-term swelling readily observed in the first two wetting steps, which
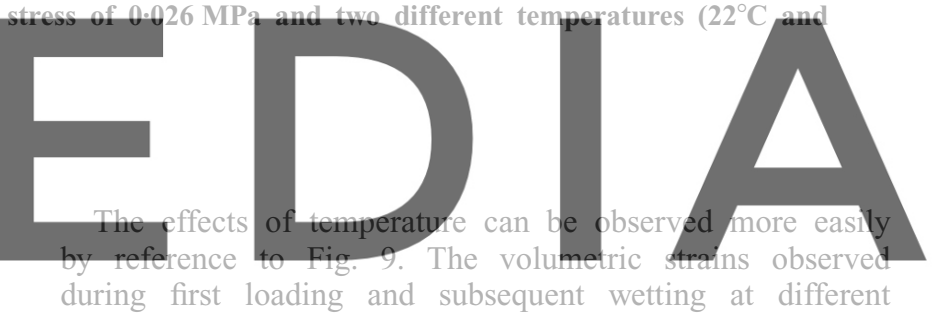

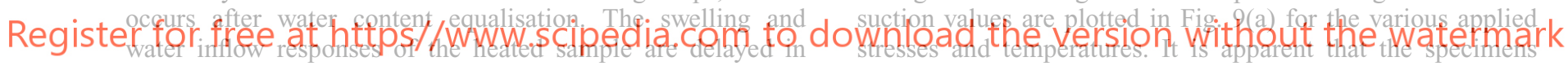

the first wetting step compared with the behaviour of the sample at room temperature. However, the transient responses of both samples converge to nearly the same time evolution in the following wetting steps. Fig. 7 presents the overall comparison of volumetric strains, water content and degree of saturation changes undergone by the high-density samples at two different temperatures and at the same stress level $(0.085 \mathrm{MPa})$. Temperature effects are reflected in a higher swelling potential in the first wetting path (path $\mathrm{BC}$ in Fig. 5(a)) and in a larger shrinkage developed in the subsequent drying path $\mathrm{CD}$. In addition, a larger degree of saturation change is observed in this drying path at high temperature, which is not recovered during the next wetting.

Figure 8 shows the variation of volumetric strains for tests carried out on high-density samples at two different temperatures and under three different values of vertical stress (stress paths can be seen in Fig. 5(a)). Although strain magnitudes are different, the basic wetting-drying behaviour is similar at the two temperatures. For the samples under vertical net stress of 0.026 and $0.085 \mathrm{MPa}$, there is a large swelling on first wetting (path $\mathrm{BC}$ ) followed by significant shrinkage strains in the first drying (path CD). At the end of this cycle, large irreversible volumetric strains are observed. Subsequent cycles exhibit smaller strains that are largely reversible. It can be noted that irreversibility reduces as the applied stress increases, practically disappearing in the test under $0.55 \mathrm{MPa}$ vertical stress. At this high applied stress the swelling potential of the soil is practically suppressed. at higher temperatures swell more, the difference being more noticeable at low vertical stresses. The enhanced swelling induced by temperature and the consequent water adsorption was also observed in swell under load tests performed on saturated bentonite-sand mixtures at different temperatures, as reported by Sherif et al. (1982). The results also suggest that a swelling pressure of around $0.5 \mathrm{MPa}$ can be estimated as giving null volume change after the combination of loading and wetting paths. Swelling pressure, involving high vertical loads, does not appear to be significantly affected by temperature (Fig. 9(a)). The data concerning water content for the same tests are summarised in Fig. 9(b). Again, larger water content changes are generally obtained for the higher temperature tests, consistent with the larger swelling observed. However, at $\left(\sigma_{\mathrm{v}}-u_{\mathrm{a}}\right)=0.55 \mathrm{MPa}$ the water content trend reverses at $s=0.45 \mathrm{MPa}$; a similar response is observed concerning the volumetric strain at the same suction level.

The degree of irreversibility of the volumetric behaviour at the two testing temperatures can be examined in Fig. 10(a), where total and reversible strain components (as defined in Fig. 8) are plotted. The reduction of irreversibility with applied load is immediately apparent. Gens \& Alonso (1992) suggested that the magnitude of the irreversible-toreversible strain ratio in a suction cycle, $\left(\varepsilon_{\mathrm{v}}-\varepsilon_{\mathrm{v}}^{\mathrm{e}}\right) / \varepsilon_{\mathrm{v}}^{\mathrm{e}}$, depends on the current generalised overconsolidation ratio. Although the value of overconsolidation ratio cannot be defined with precision here, Fig. 10(b) shows that this ratio 


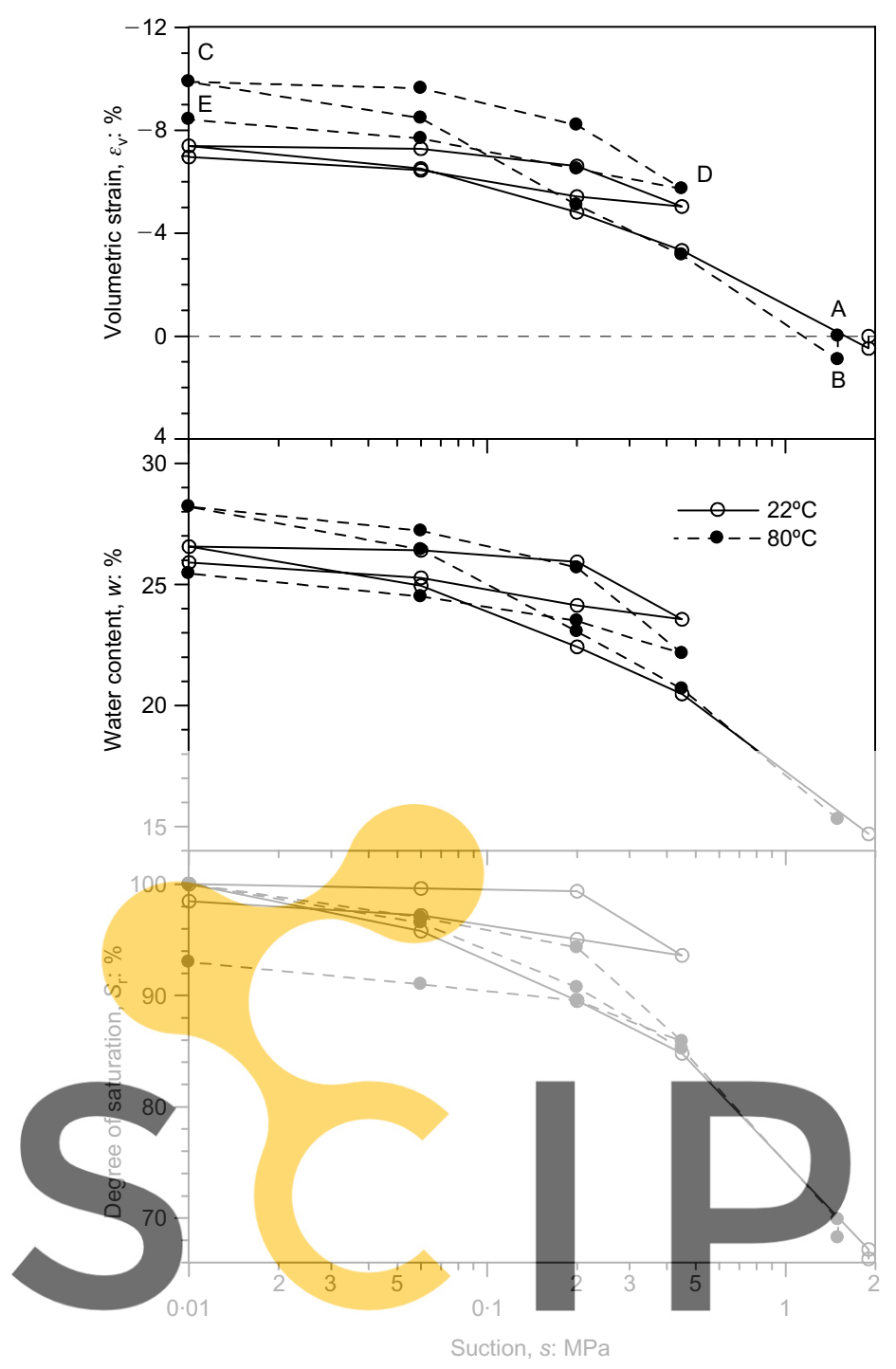

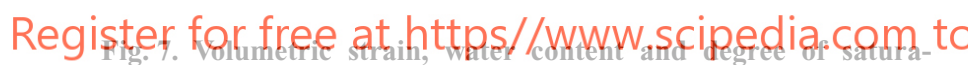
tion changes in isothermal wetting-drying tests carried out on high-density samples $\left(\gamma_{\mathrm{d}}=16.7 \mathrm{kN} / \mathrm{m}^{3}\right)$ at constant vertical net stress of $0.085 \mathrm{MPa}$ and two different temperatures $\left(22^{\circ} \mathrm{C}\right.$ and $\left.80^{\circ} \mathrm{C}\right)$

increases significantly as applied load reduces, in accordance with the predicted trend. It is interesting to note that the relationship appears to be insensitive to the value of temperature.

Figure 11 presents a comparison of volumetric strains, water content and degree of saturation changes for the tests carried out on low-density soil $\left(\gamma_{\mathrm{d}}=13.7 \mathrm{kN} / \mathrm{m}^{3}\right)$ at two different temperatures $\left(22^{\circ} \mathrm{C}\right.$ and $\left.80^{\circ} \mathrm{C}\right)$ for a vertical net stress of $1.20 \mathrm{MPa}$. The stress path is shown in Fig. 5(a). The volumetric strains of the tests on low-density samples under three different values of vertical stress and at two different temperatures are plotted in Fig. 12. The observed behaviour is quite different from that of the high-density specimens. At high stresses $\left(\sigma_{\mathrm{v}}-u_{\mathrm{a}}=0.30\right.$ and $\left.1.2 \mathrm{MPa}\right)$, first wetting (path $\mathrm{BC}$ ) causes large irreversible compression (collapse) strains. Under these larger loads, the collapse of the soil structure overcomes the swelling potential of the soil that develops during wetting. In conventional soil models (Alonso et al., 1990) this collapse is explained by the activation of the loading-collapse LC yield curve in the suction-mean net stress space. At low applied stresses $\left(\sigma_{\mathrm{v}}-u_{\mathrm{a}}=0.085 \mathrm{MPa}\right)$, swelling is dominant in the early stages but collapse strains prevail when suction approaches zero. It is interesting to note that, for all stress levels, the subsequent drying stage (path CD) results in significant compressive volumetric strains that are basically irreversible. In contrast, subsequent wetting-drying cycles exhibit practically reversible behaviour.

To examine more directly the effects of temperature on low-density soil, Figs 13 and 14 present the volumetric strains measured during the first loading and first wetting stages at the two test temperatures. Fig. 13 shows the cumulative volumetric strains undergone by the samples (equivalent plot to that presented for the high-density samples in Fig. 9(a)), whereas in Fig. 14 the wetting strains have been plotted separately for the different suction-controlled steps used in the tests. It can be observed in Fig. 14 that the main temperature effect on these low-density samples is found in the loading stage at constant water content, in which larger compression strains are measured at higher temperatures. The strains observed at the wetting stage are very similar at the two temperature levels. Therefore it can be stated that collapsibility, unlike swelling, is not enhanced at higher temperatures, at least for the range of stress paths and material used in the experiments. A maximum collapse zone is identified from the second wetting step onwards, a zone that moves to lower stress levels as saturation is approached.

Figure 15 combines the data of the shrinkage strains, water content and degree of saturation changes experienced by the low- and high-density samples at different temperatures in the first suction increase path CD. Larger shrinkage strains, water content and degree of saturation changes are

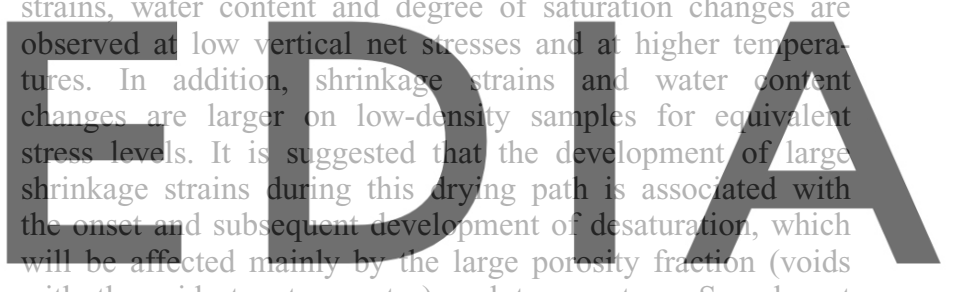

with the widest entry routes) and temperature. Samples at

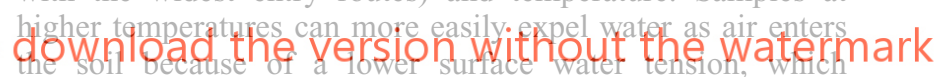
affects the meniscus-receding mechanism.

Finally, the approximately reversible behaviour obtained in the final drying-wetting cycle is examined. Fig. 16(a) shows the volumetric swelling strains obtained in the wetting path DE for various vertical stresses and at two different temperatures for low- and high-density samples. It can be observed that, for all values of applied vertical stress, the deformability of the soil is higher at higher temperatures. This tendency coincides with the observations on compressibility during first loading at a higher suction (Fig. 14). Similarly, the water content variation is also higher in the tests carried out at $80^{\circ} \mathrm{C}$.

\section{Non-isothermal tests on high-density samples}

Two non-isothermal paths were applied to high-density specimens under an applied stress of $0.026 \mathrm{MPa}$ and suction values of 0.06 and $0.20 \mathrm{MPa}$ respectively. The generalised stress paths followed are plotted in Fig. 5(b) in suctiontemperature space, where it can be noted that the tests involved the performance of heating-cooling cycles. Fig. 17(a) shows the evolution of volumetric strains and Fig. 18(a) the variation of water content for the two tests. The results of the isothermal wetting tests at $22^{\circ} \mathrm{C}$ and $80^{\circ} \mathrm{C}$ have been added for comparison. Considering the temperature as a new variable in a generalised stress path definition, it could be stated that soil behaviour is largely stress path independent under thermal actions. Although the final states 


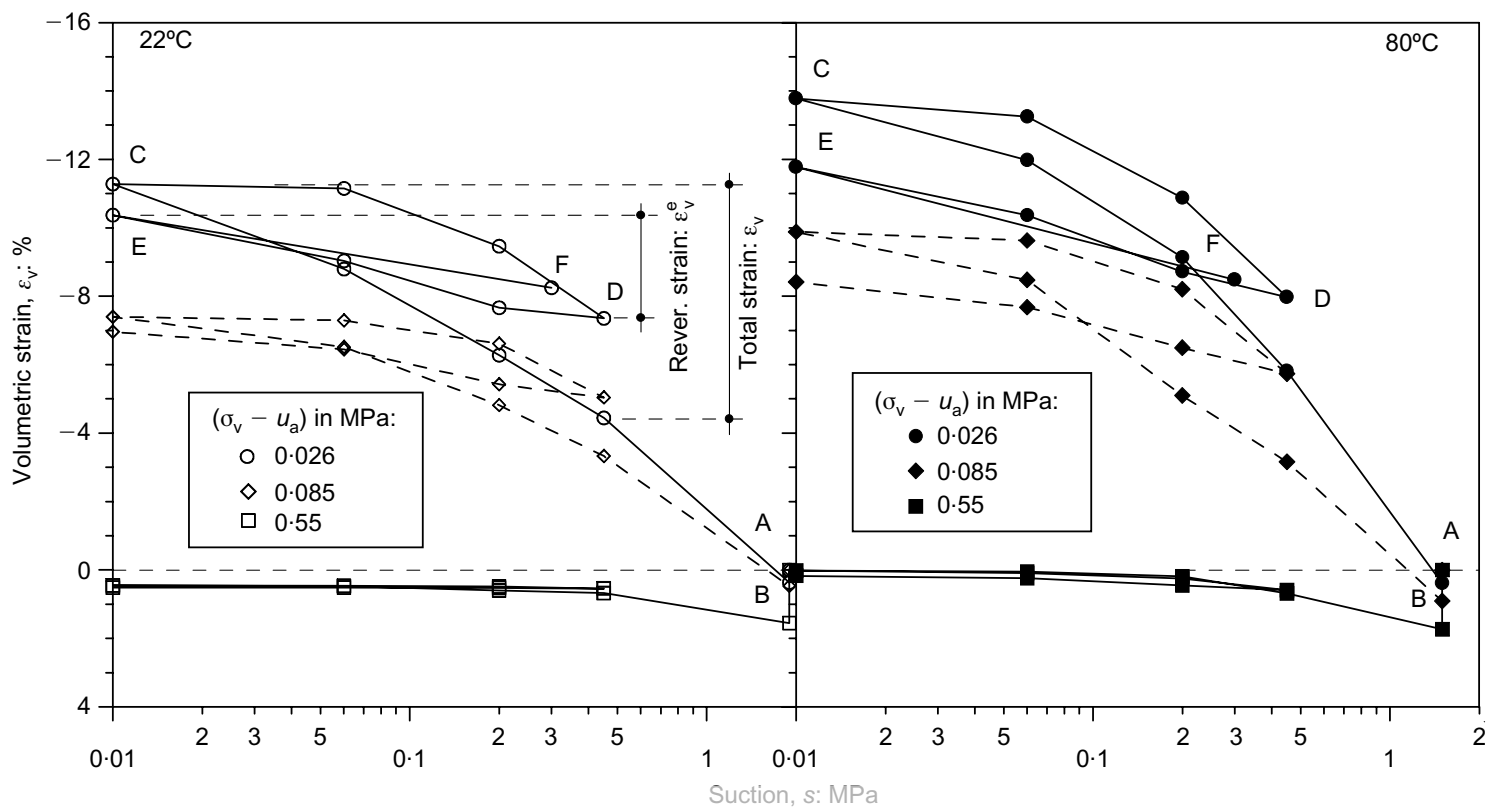

Fig. 8. Variation of volumetric strains in isothermal wetting-drying tests carried out on high-density samples $\left(\gamma_{\mathrm{d}}=16.7 \mathrm{kN} / \mathrm{m}^{3}\right)$ using two different temperatures $\left(22^{\circ} \mathrm{C}\right.$ and $\left.80^{\circ} \mathrm{C}\right)$
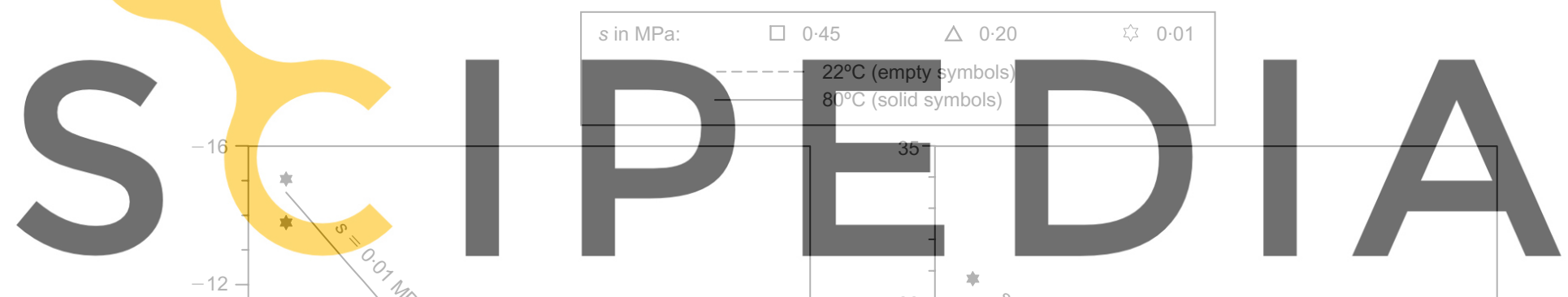

Register for free at https//www.scipedia.com to download the Q a

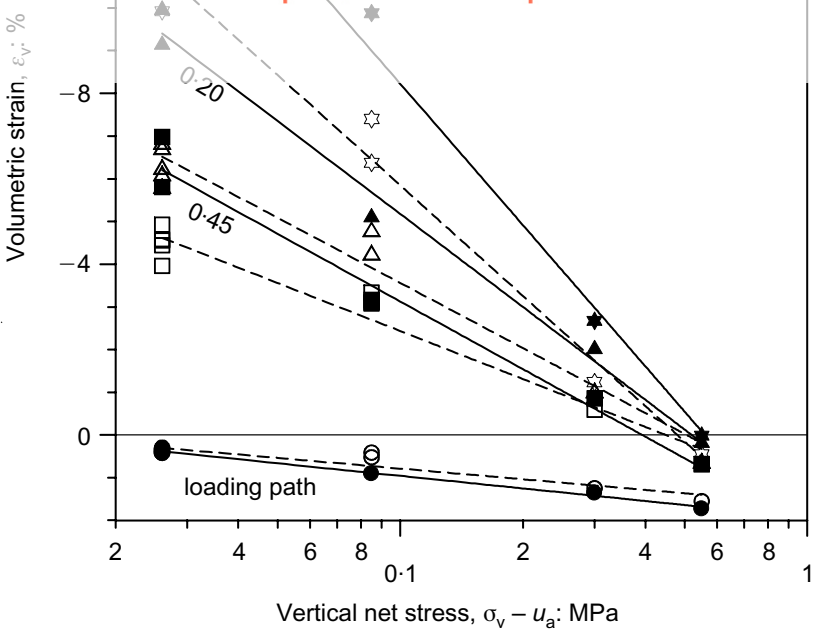

(a)

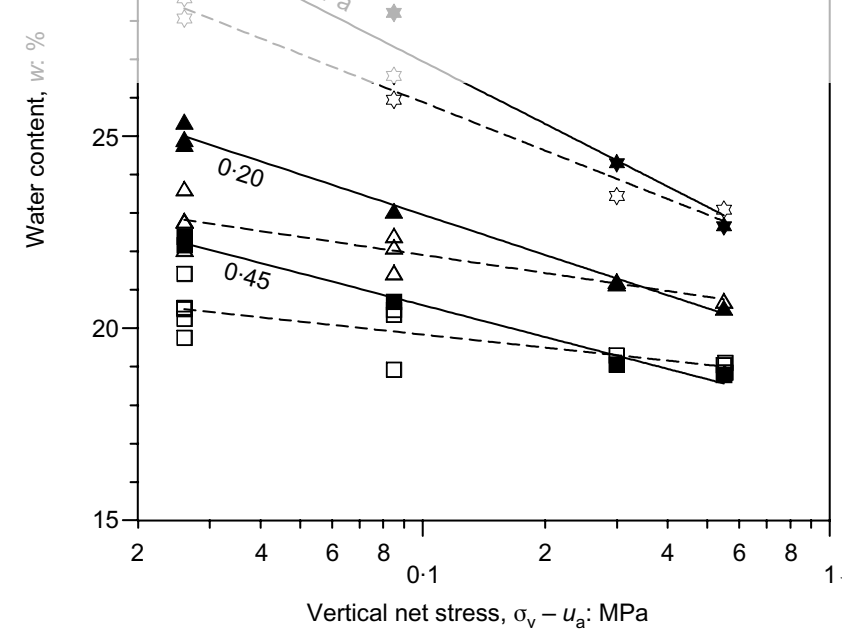

(b)

Fig. 9. Results from the first loading and first wetting stages of isothermal tests performed on high-density samples $\left(\gamma_{\mathrm{d}}=16 \cdot 7 \mathrm{kN} / \mathrm{m}^{3}\right)$ at two different temperatures $\left(22^{\circ} \mathrm{C}\right.$ and $\left.80^{\circ} \mathrm{C}\right)$ : (a) volumetric strains; (b) water content

do not coincide exactly, most of the differences arise from the variability in the common part of the stress path. It is interesting to note (Figs 17(b) and 18(b)) that significant irreversible volumetric strains and water content changes were observed on cooling (path $\mathrm{d}-\mathrm{e}$ ). However, in the next cooling-heating cycle (path $\mathrm{d}-\mathrm{e}-\mathrm{f}$ ) irreversible behaviour largely disappears, and only some small strain and water content accumulation was observed. The volumetric thermal 

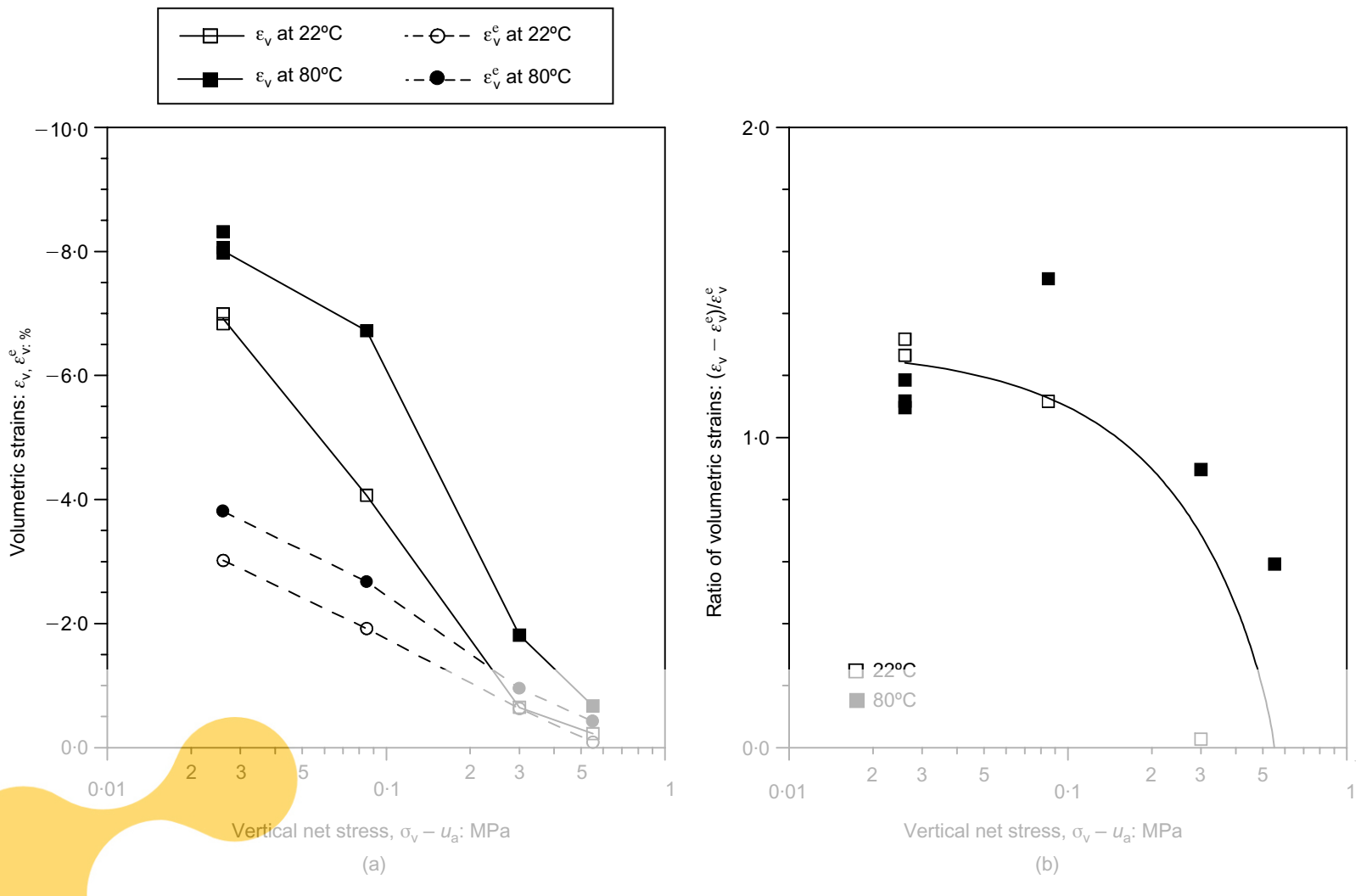

(b)

Fig. 10. Results from first wetting stages of isothermal tests performed on high-density samples $\left(\gamma_{\mathrm{d}}=16.7 \mathrm{kN} / \mathrm{m}^{3}\right)$ at two different temperatures $\left(22^{\circ} \mathrm{C}\right.$ and $\left.80^{\circ} \mathrm{C}\right)$ : (a) total and reversible volumetric strains; (b) dependence of ratio between
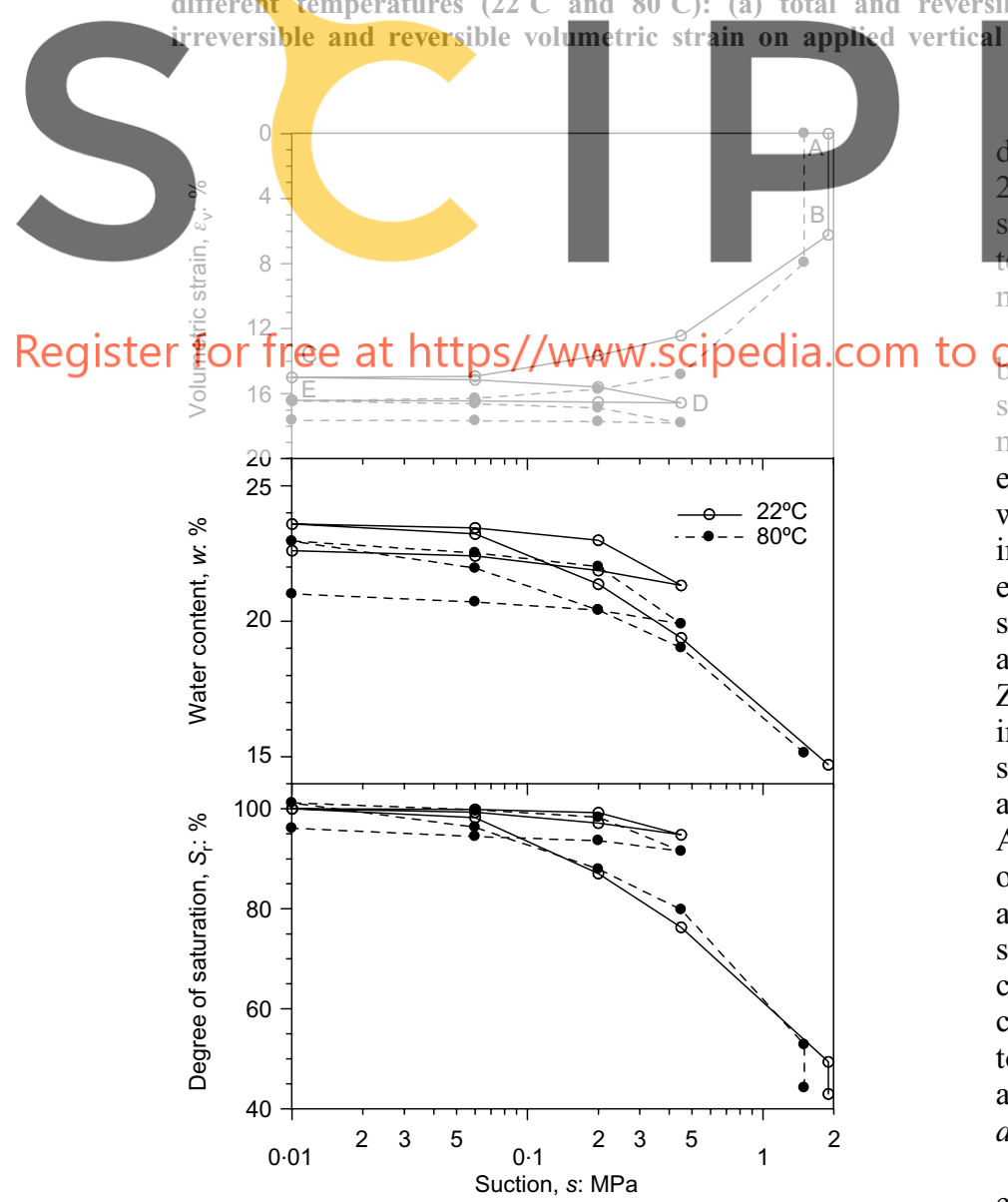

Fig. 11. Volumetric strain, water content and degree of saturation changes in isothermal wetting-drying tests carried out on low-density samples $\left(\gamma_{d}=13 \cdot 7 \mathrm{kN} / \mathrm{m}^{3}\right)$ at constant vertical net stress of $1.20 \mathrm{MPa}$ and two different temperatures $\left(22^{\circ} \mathrm{C}\right.$ and $\left.80^{\circ} \mathrm{C}\right)$

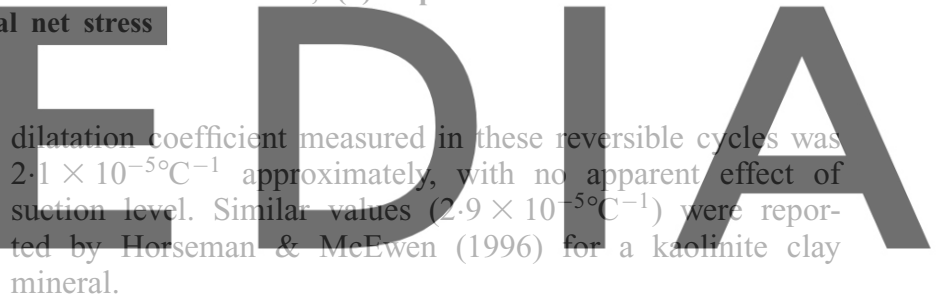

mineral.

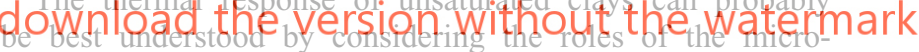
structure and the macrostructure. Phenomena occurring at microstructural level have been proposed by various authors: expansion of the mineralogical components and the adsorbed water (Baldi et al., 1988), physico-chemical changes affecting diffusive double layers (Morin \& Silva, 1984), thermally enhanced water adsorption (Sherif et al., 1982), and microstructural disturbances that enhance the transition from adsorbed water to free water (Ma \& Hueckel, 1992, 1993; Zhang et al., 1993). On the other hand, thermally induced irreversible effects are more likely to be associated with structural rearrangements at the macrostructural scale. In accordance with the framework put forward by Gens \& Alonso (1992), the thermal expansion of the microstructure on initial heating (path $\mathrm{c}-\mathrm{d}$ in Figs 17(b) and 18(b)) may affect the macrostructure of the clay skeleton in an irreversible way. Those effects are not erased in the subsequent cooling path $\mathrm{d}-\mathrm{e}$. Strain accumulation in the quasi-reversible cooling-heating cycles (paths $\mathrm{d}-\mathrm{e}-\mathrm{f}$ ) may be partly related to the progressive subdivision of clay particles, following the analogy of suction-induced strain accumulation (Saiyouri et al., 1998).

A significant observation is the apparent overconsolidation effect noted in Figs 17(b) and 18(b) where yield is observed for the tests carried out with suction at $s=0.20 \mathrm{MPa}$. As shown in these figures, the first heating stage up to $40^{\circ} \mathrm{C}$ takes place without appreciable volumetric strain or water content increase. However, when this temperature is exceeded, the volumetric strains and water content increase 

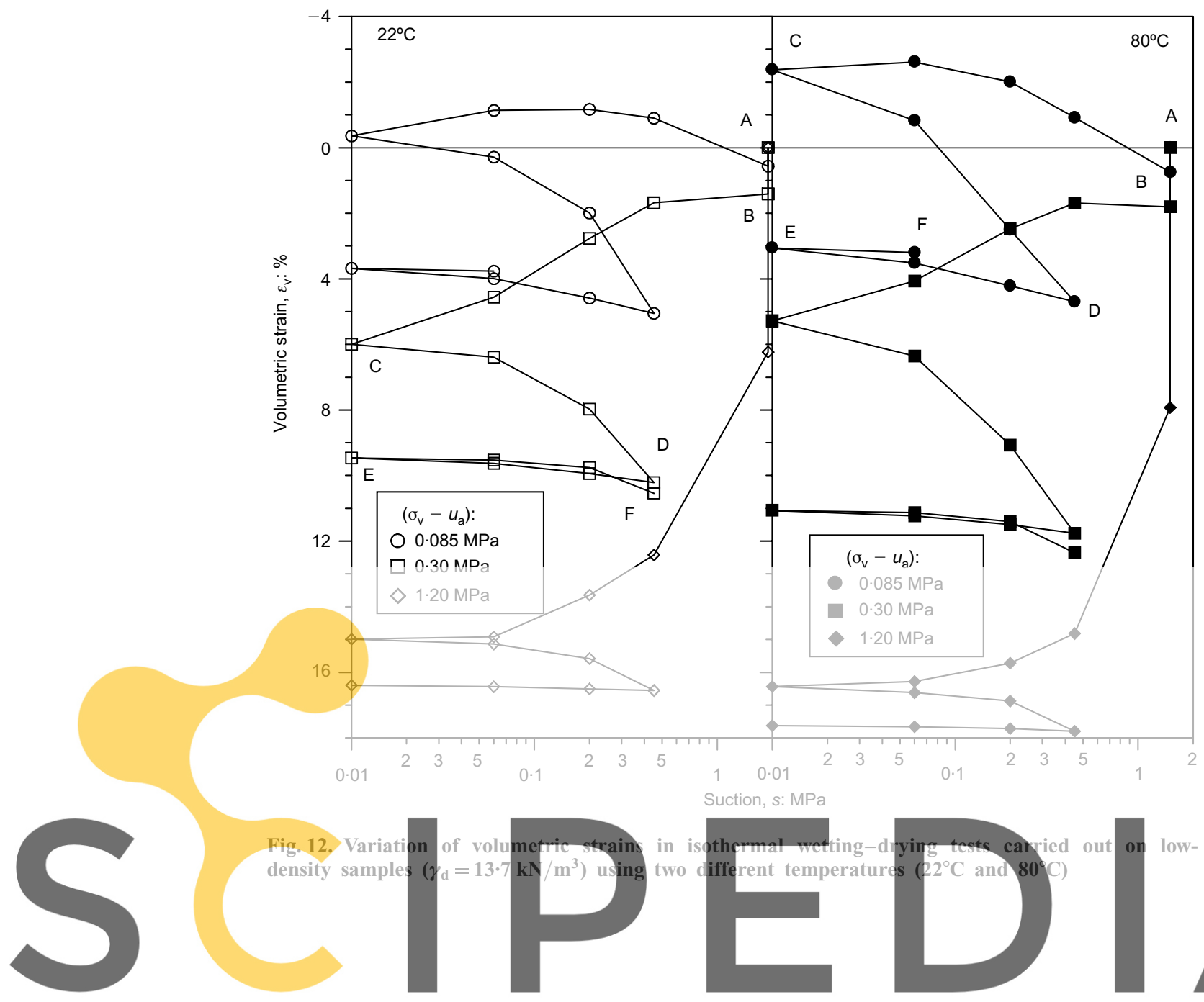

Fig. 12. Variation of volumetric strains

Suction, s: MPa

density samples $\left(\gamma_{d}=13.7\right.$

Register for free at https//www.scipedia.com to download the version without the watermark

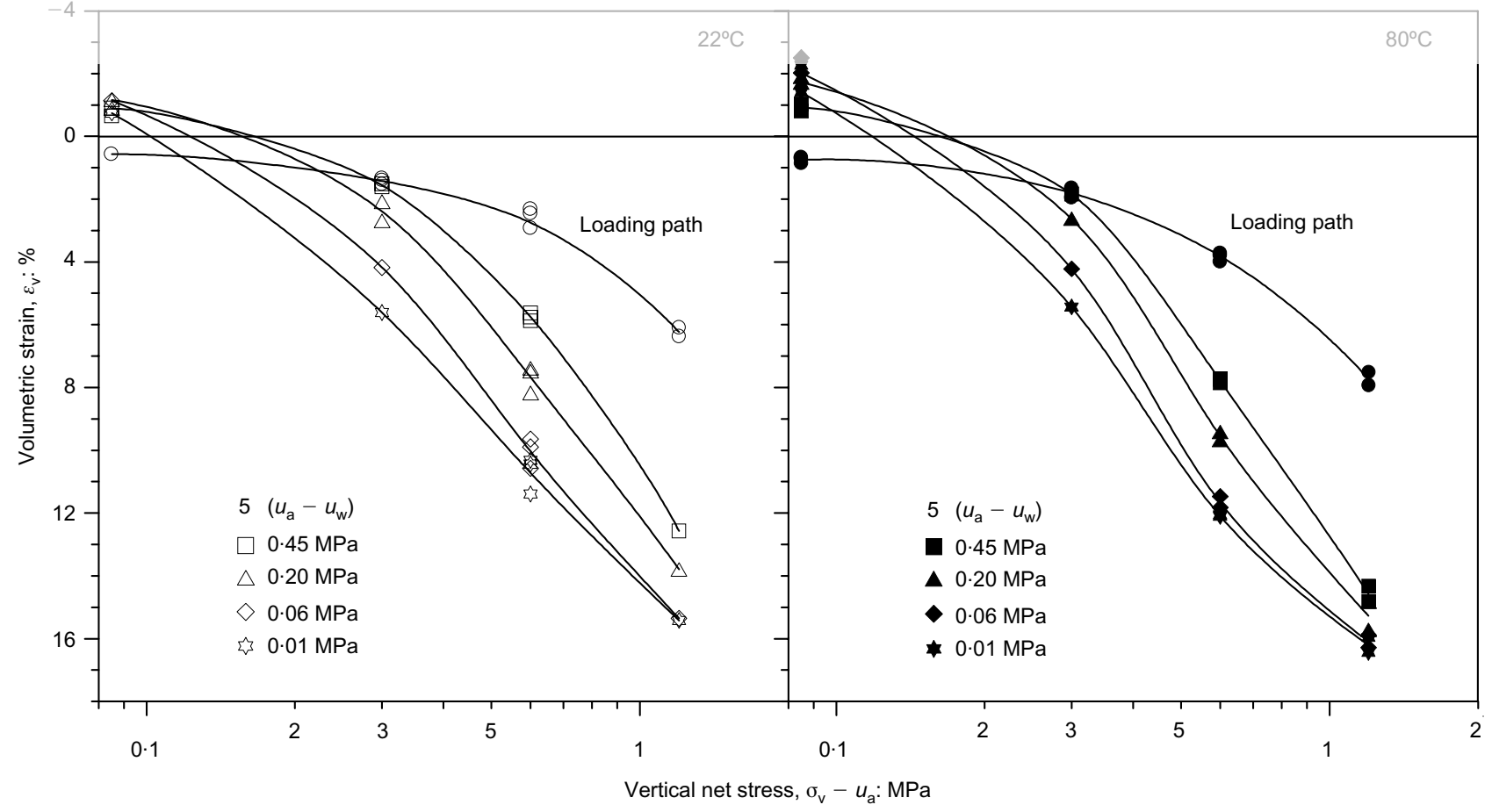

Fig. 13. Results from first loading and first wetting stages of isothermal tests performed on low-density $\mathrm{samples}\left(\gamma_{\mathrm{d}}=13 \cdot 7 \mathrm{kN} / \mathrm{m}^{3}\right)$ at two different temperatures $\left(22^{\circ} \mathrm{C}\right.$ and $\left.80^{\circ} \mathrm{C}\right)$ 


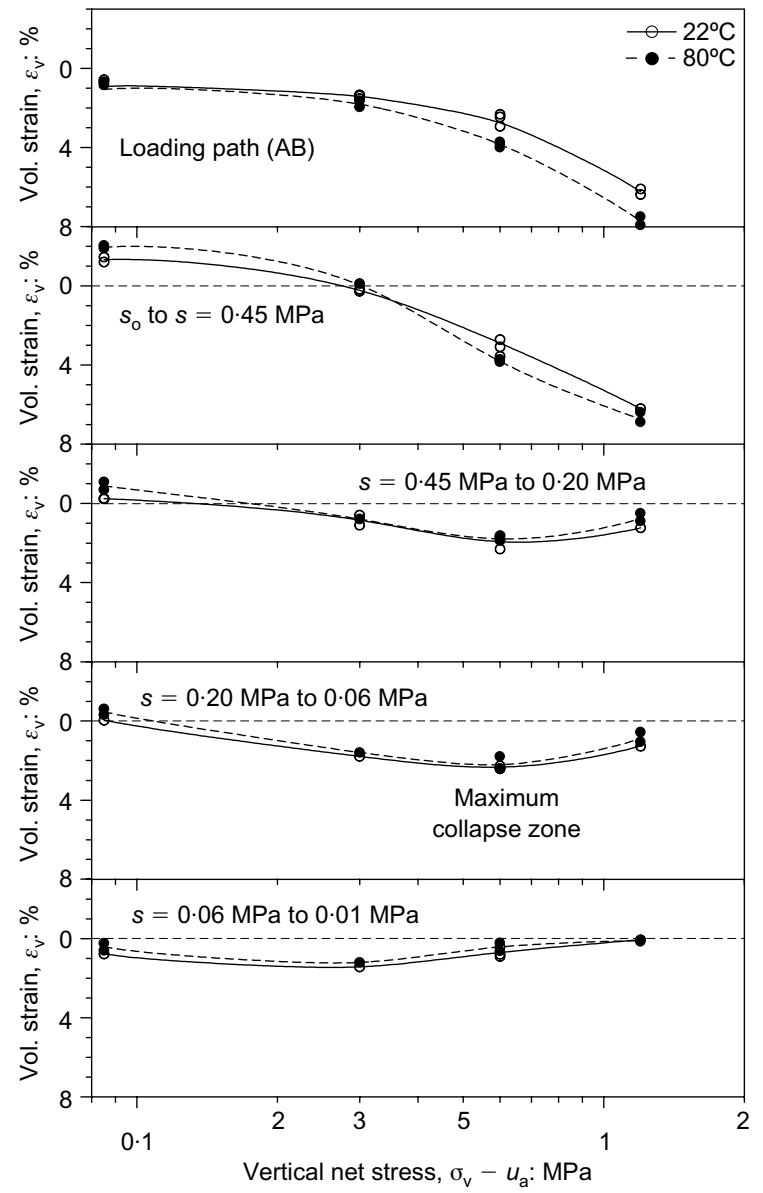

Fig. 14. Volumetric strains from first loading and first wetting stages of isothermal tests performed on low-density samples $\left(\gamma_{\mathrm{d}}=13.7 \mathrm{kN} / \mathrm{m}^{3}\right)$ at two different temperatures $\left(22^{\circ} \mathrm{C}\right.$ and $\left.\mathbf{8 0}^{\circ} \mathrm{C}\right)$

considerably and develop irreversible features. It is likely, therefore, that the description of thermal effects can benefit from thermoplasticity concepts, even in the case of highdensity samples that, probably, are far from the main yield surface.

\section{Constant volume paths on low-density samples}

Two swelling pressure tests were performed on low-density samples, one at $22^{\circ} \mathrm{C}$ and the other at $80^{\circ} \mathrm{C}$. The tests started from the as-compacted conditions, and suction was reduced to zero with the volume of the sample maintained constant throughout. After saturation a drying-wetting cycle was performed again, with a no-volume-change condition applied. The suction changes were applied in steps, leaving sufficient time for equilibration at the end of each step. Fig. 19 shows the evolution of vertical net stress for the two tests; the horizontal dashed lines indicate the suction levels at the various equilibration stages. For intermediate states, the observed water content changes were used to estimate the value of suction by interpolation between the equilibrium states. Because of the large suction variation involved in the first suction reduction step, the estimation of the suction was based directly on the retention curve presented in Fig. 2.

The swelling stress paths shown in Fig. 19 are characteristic of low-density materials. Two distinct phases can be identified. In the first phase $(A B)$, vertical stresses increase to compensate for the swelling strains caused by suction reduction. However, on reaching point $\mathrm{B}$, irreversible com- pression strains start to develop. In conventional models for unsaturated soils, this event corresponds to the stress state reaching the LC yield curve (Alonso et al., 1999), and the phenomenon associated with it is usually designated as collapse. From that point on, suction-induced compression (collapse) strains predominate, and the vertical stress must reduce to maintain the constant-volume condition. In very expansive materials there is sometimes a third stage in which the vertical pressure rises again because the swelling of clay minerals becomes dominant close to saturation. This third stage has not been observed in these tests, as Boom clay is not a highly expansive material. Inspecting Fig. 19, it is apparent that the high-temperature sample reaches the LC surface at a lower stress than the specimen at $22^{\circ} \mathrm{C}$, indicating that the LC surface moves to the left as temperature increases. This is also reflected in the fact that the final swelling pressure on saturation is smaller in the hotter sample, although the differences are now somewhat smaller. From an elasto-plastic point of view this reduction is achieved by introducing the dependence of the saturated preconsolidation stress on temperature through a thermal softening function (Hueckel \& Borsetto, 1990; Gens, 1995). In the subsequent suction increase-decrease cycle (CDE) the samples display a quite reversible response, coming back to practically the same value of saturated swelling stress.

\section{Isothermal loading-unloading results (low-and high-density samples)}

Loading-unloading cycles were applied to low- and highdensity samples at two values of temperature, $22^{\circ} \mathrm{C}$ and $80^{\circ} \mathrm{C}$, after a series of wetting-drying cycles. The stress paths followed are shown in Figs 5(c) and 5(d). The results in terms of variation of specific volume, $v(1+e$, where $e$ is the void ratio), with vertical net stress are shown in Figs 20 and 21 . Very distinct pre-yield and post-yield behaviour can be identified in the compression curves plotted. The values of the yield stresses are controlled by the irreversible strains developed in the previous wetting-drying cycles, so that any possible thermal effects are masked. In the high-density samples irreversible swelling strains tend to reduce the loading yield stress, whereas in the low-density samples collapse deformation increases the value of the yield stress (Fig. 21). The yield stresses exhibited by the samples after collapse are significantly larger than the yield stresses observed in the swelling pressure tests (Fig. 19).

The values of the post-yield compressibility parameter ( $\lambda_{\text {oed }}$, slope of the normal compression line in the $v-\ln \left(\sigma_{\mathrm{v}}-u_{\mathrm{a}}\right)$ plane) are also indicated in the figures. Generally, larger post-yield compressibility values are observed at higher temperatures. Also, post-yield compressibility reduces as suction increases. The overall pattern of the variation of pre-yield ( $\kappa_{\text {oed }}$, slope of the unloading-reloading line in the $v-\ln \left(\sigma_{\mathrm{v}}-u_{\mathrm{a}}\right)$ plane $)$ and the post-yield $\left(\lambda_{\text {oed }}\right)$ compressibility parameters with suction and temperature is presented in Fig. 22, where some additional compressibility data for the low-density soil from Romero (1999) have been added. The trend of the post-yield compressibility increasing with temperature and decreasing with suction can be clearly noted. In contrast, the pre-yield compressibility parameter does not appear to be sensitive to temperature. However, some small pre-yield compressibility reduction is observed at increasing suctions.

Comparison with equivalent results regarding thermal effects on the compressibility of saturated soils is difficult, as there is no agreement on this topic among different researchers. Campanella \& Mitchell (1968), Eriksson (1989), Tidfors \& Sällfors (1989), Lingnau et al. (1995, 1996), Belanteur et al. (1997) and Robinet et al. (1997) reported no 


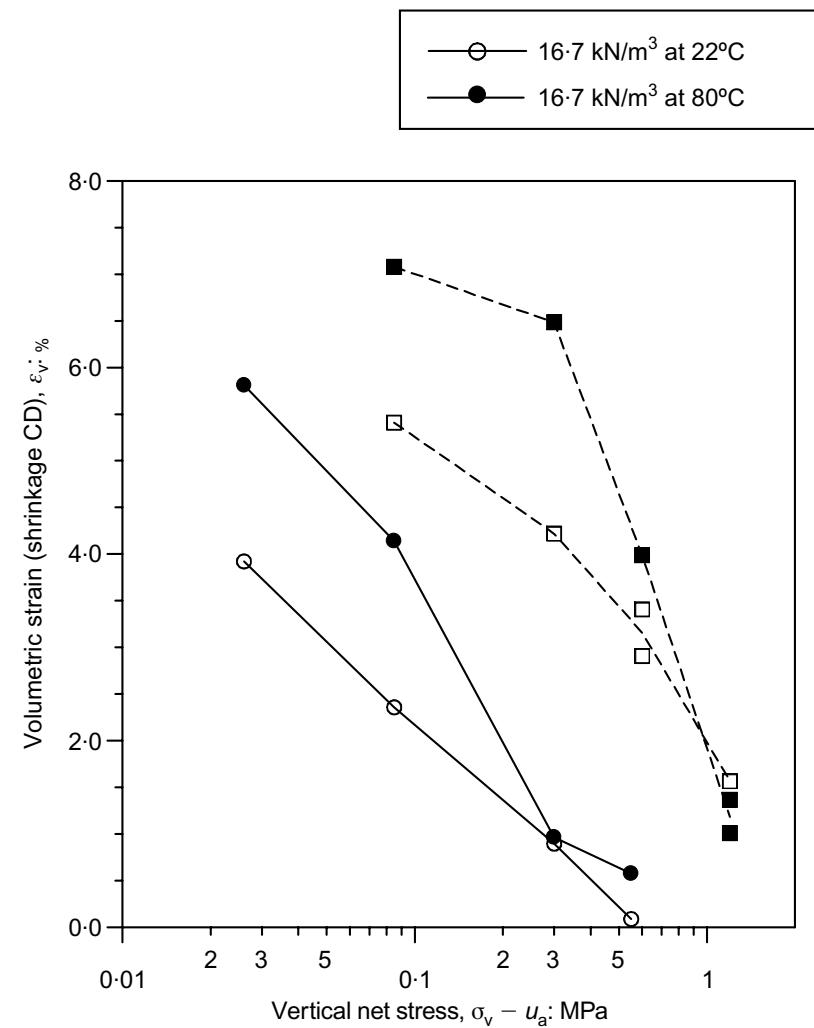

(a)

\section{- - $-13.7 \mathrm{kN} / \mathrm{m}^{3}$ at $22^{\circ} \mathrm{C}$ \\ $-13.7 \mathrm{kN} / \mathrm{m}^{3}$ at $80^{\circ} \mathrm{C}$}

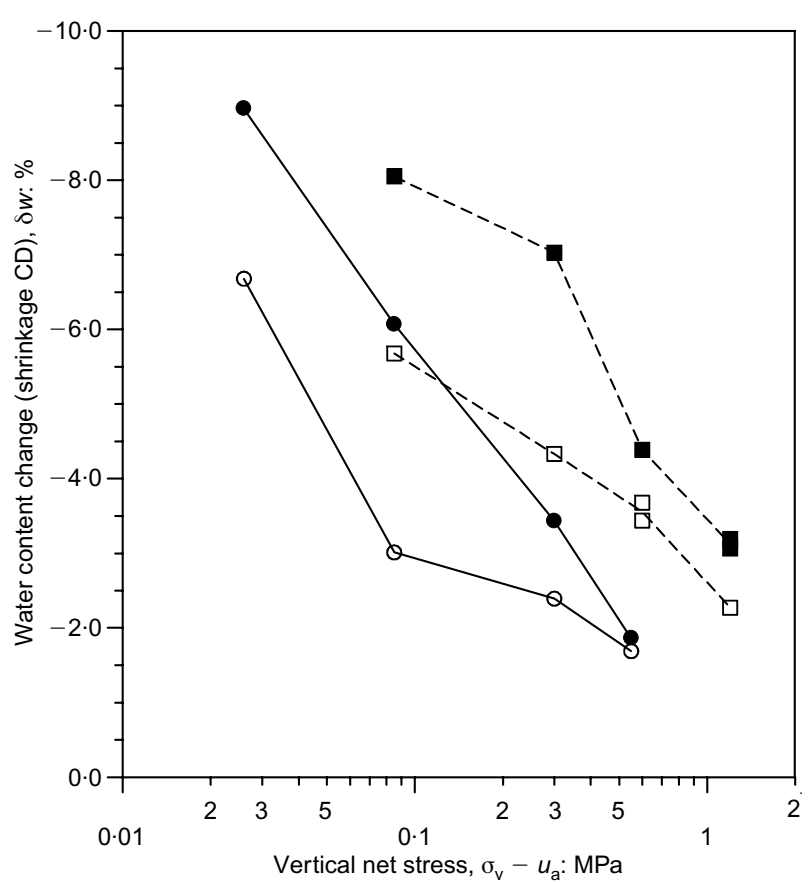

(b)

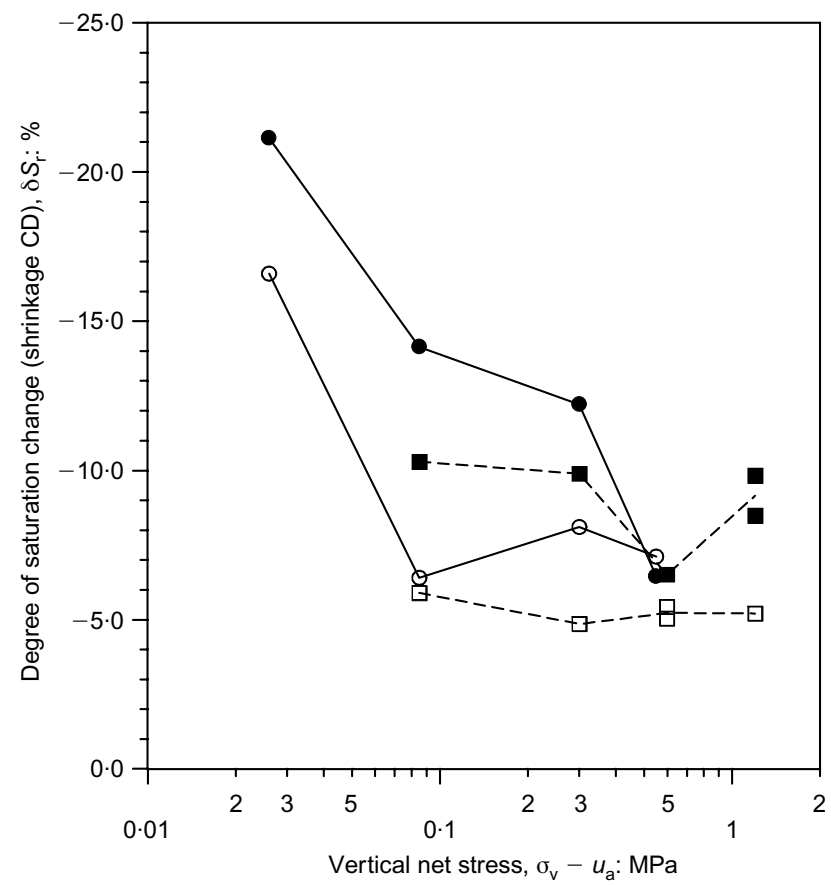

(c)

Fig. 15. Results from first drying stages of isothermal tests performed on high- and low-density samples $\left(\gamma_{\mathrm{d}}=16 \cdot 7\right.$ and $\left.13 \cdot 7 \mathrm{kN} / \mathrm{m}^{3}\right)$ at two different temperatures $\left(22^{\circ} \mathrm{C}\right.$ and $\left.80^{\circ} \mathrm{C}\right)$ : (a) volumetric strains; (b) water content changes; (c) degree of saturation changes

temperature dependence of the virgin compressibility parameter. However, Plum \& Esrig (1969) and Akagi \& Komiya (1995) detected limited thermal dependence of compressibility indices, larger compressibility values being observed at higher temperatures. On the other hand, the convergence of the compressibility curves at higher stresses was observed by Tanaka et al. (1997) testing reconstituted illitic clay, but in this case the soil exhibited higher compressibility values at lower temperatures.

\section{CONCLUSIONS}

A testing programme has been carried out using an oedometer apparatus that allows the independent control of 


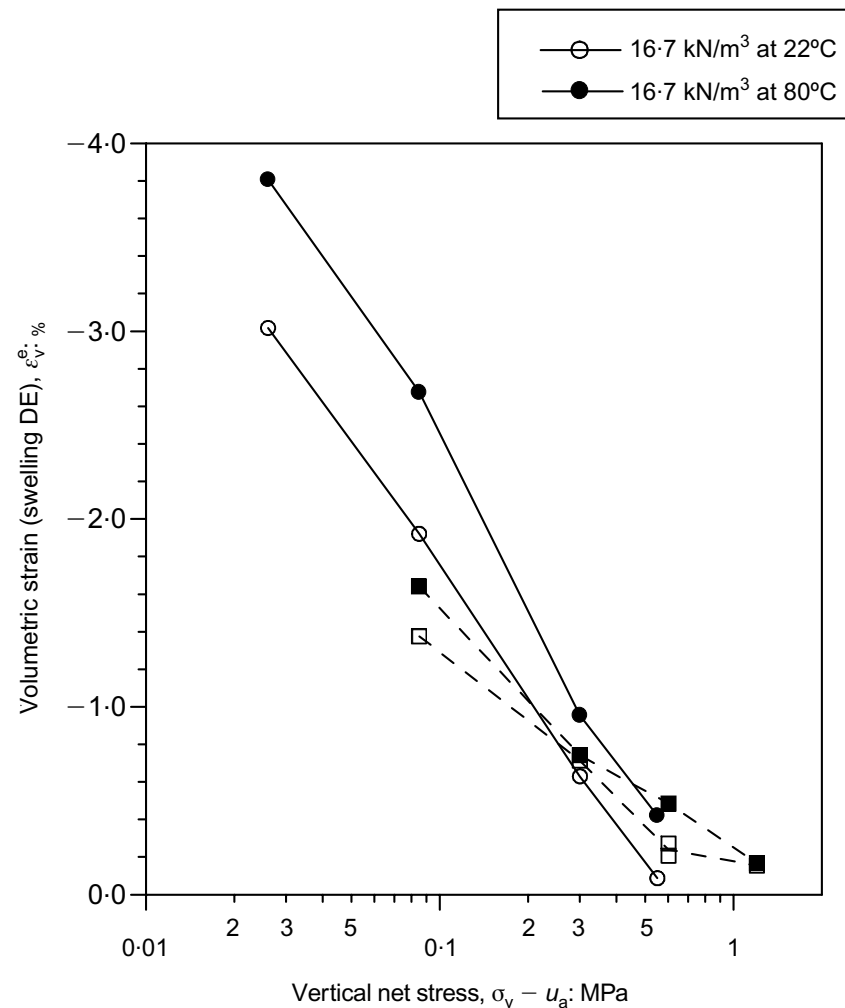

(a) $--\boxminus--13 \cdot 7 \mathrm{kN} / \mathrm{m}^{3}$ at $22^{\circ} \mathrm{C}$

$-\mathbf{- 1}-13.7 \mathrm{kN} / \mathrm{m}^{3}$ at $80^{\circ} \mathrm{C}$

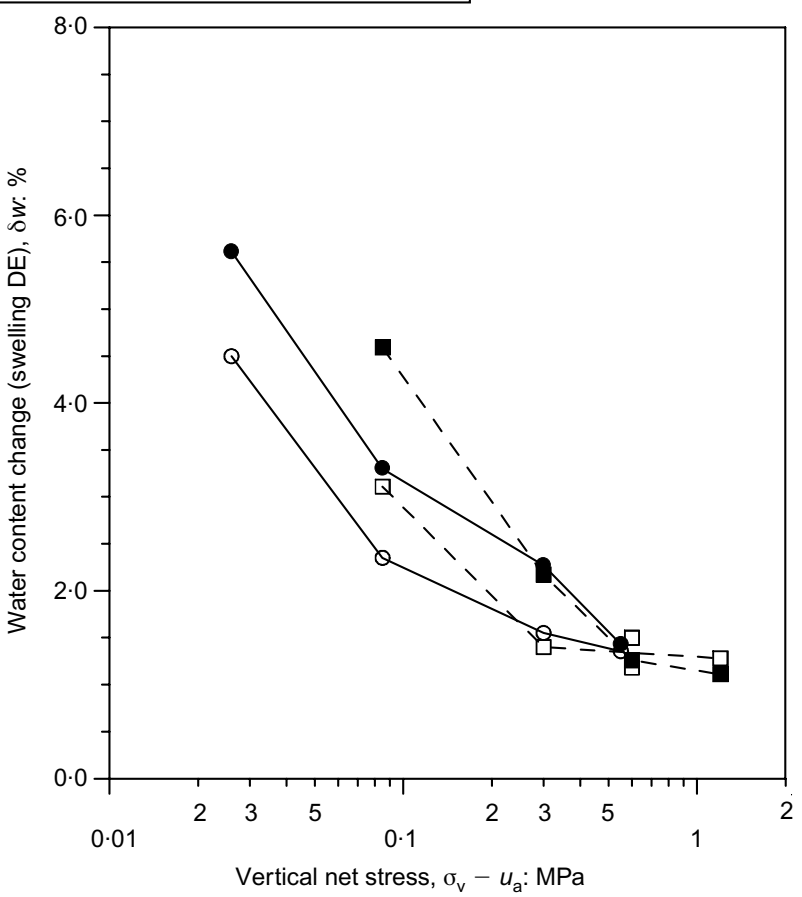

(b)

Fig. 16. Observed soil behaviour in wetting path $D E$ in tests performed on high- and low-density samples $\left(\gamma_{d}=16 \cdot 7\right.$ and $\left.13 \cdot 7 \mathrm{kN} / \mathrm{m}^{3}\right)$ at two different temperatures $\left(22^{\circ} \mathrm{C}\right.$ and $\left.80^{\circ} \mathrm{C}\right)$ : (a) volumetric strains; (b) water content changes

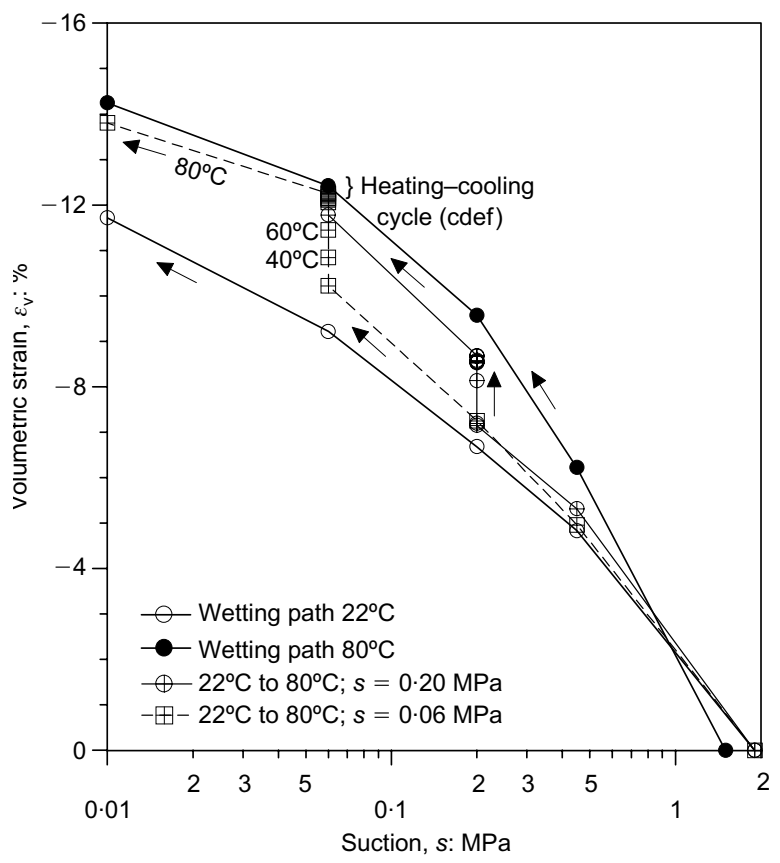

(a)

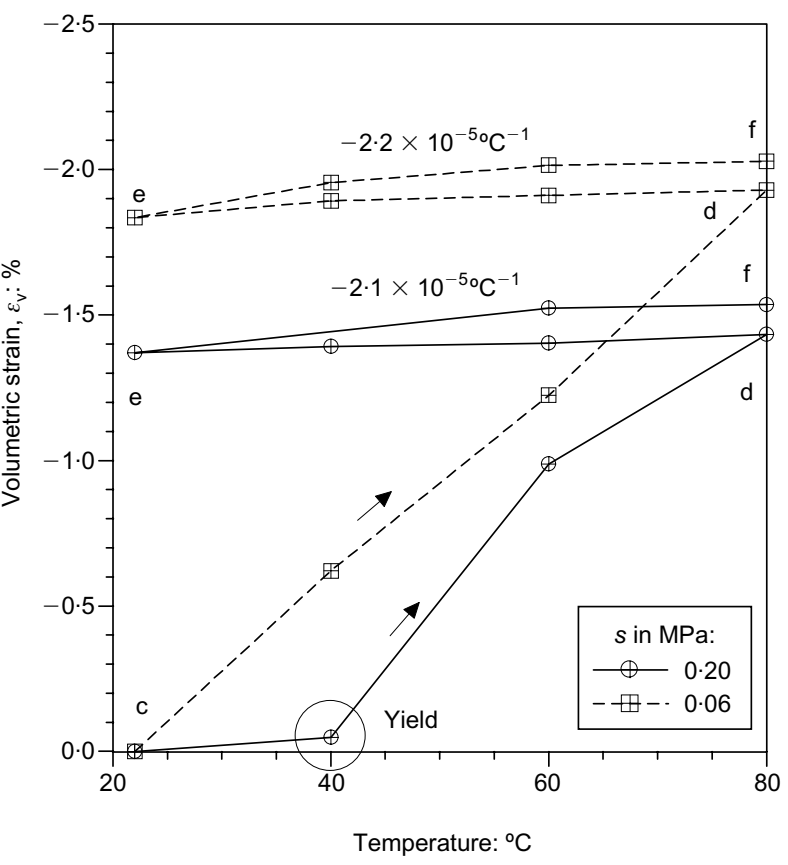

(b)

Fig. 17. Results from non-isothermal tests carried out on high-density samples $\left(\gamma_{d}=16 \cdot 7 \mathrm{kN} / \mathrm{m}^{3}\right)$ at two different suctions and the same vertical net stress of $0.026 \mathrm{MPa}$ : (a) volumetric strains (the results of the isothermal wetting tests at $22^{\circ} \mathrm{C}$ and $80^{\circ} \mathrm{C}$ have been added for comparison); (b) variation of volumetric strains with temperature 


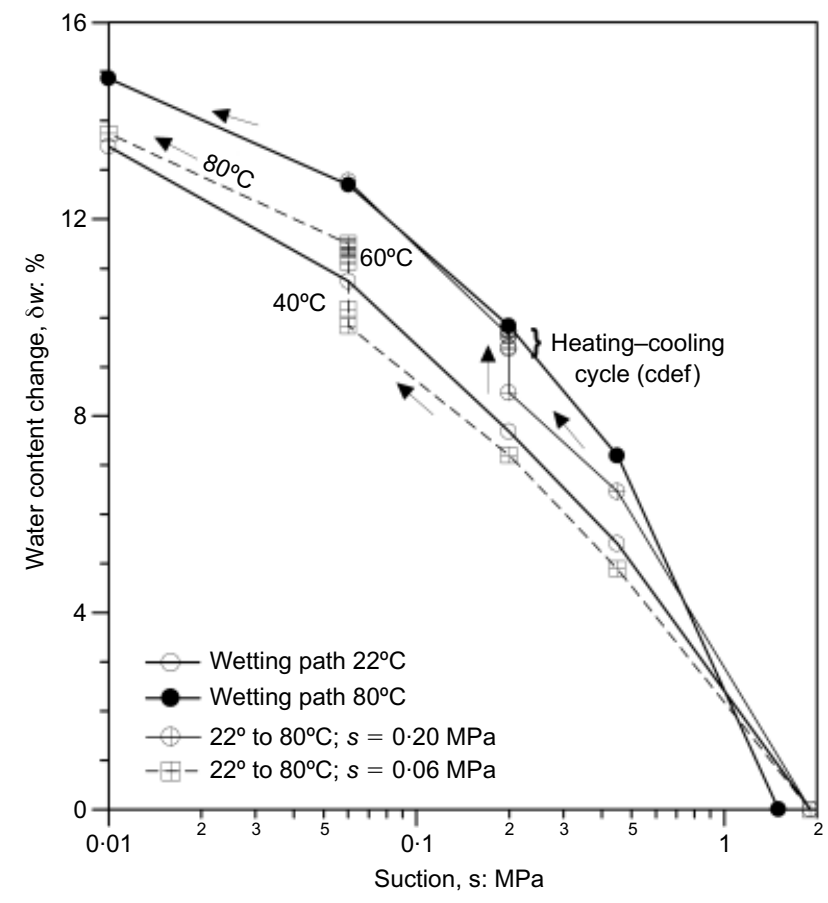

(a)

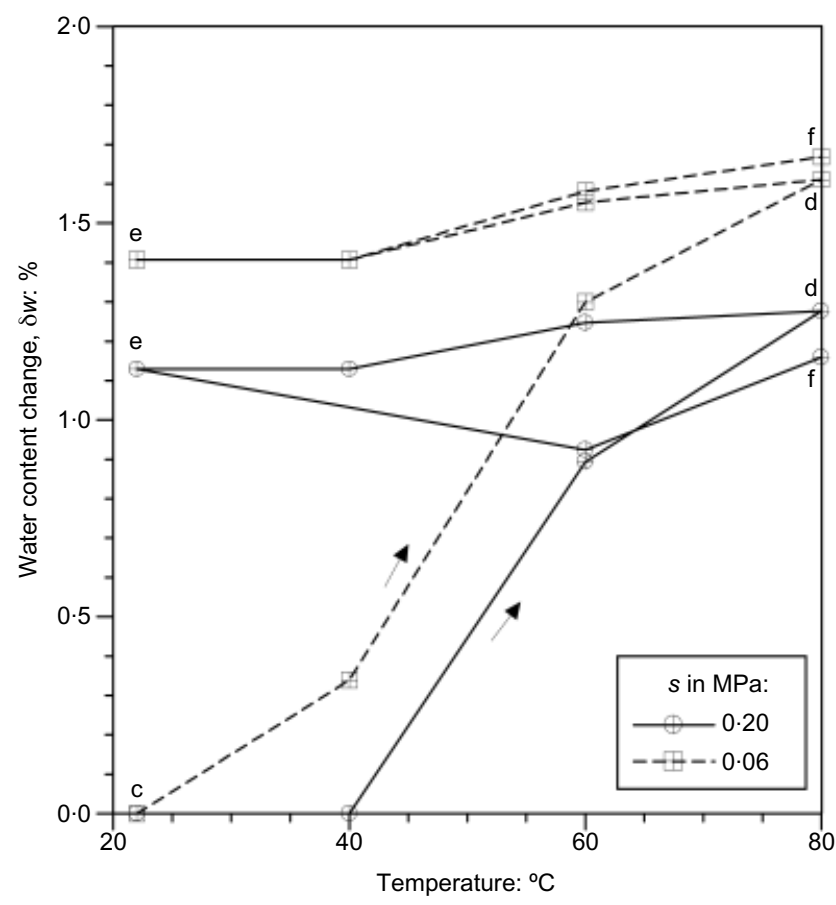

(b)

Fig. 18. Results from non-isothermal tests carried out on high-density samples $\left(\gamma_{d}=16 \cdot 7 \mathrm{kN} / \mathrm{m}^{3}\right)$ at two different suctions and the same vertical net stress of $0.026 \mathrm{MPa}$ : (a) water content changes (the results of the isothermal wetting tests at $22^{\circ} \mathrm{C}$ and $80^{\circ} \mathrm{C}$ have been added for comparison); (b) variation of water content changes with temperature

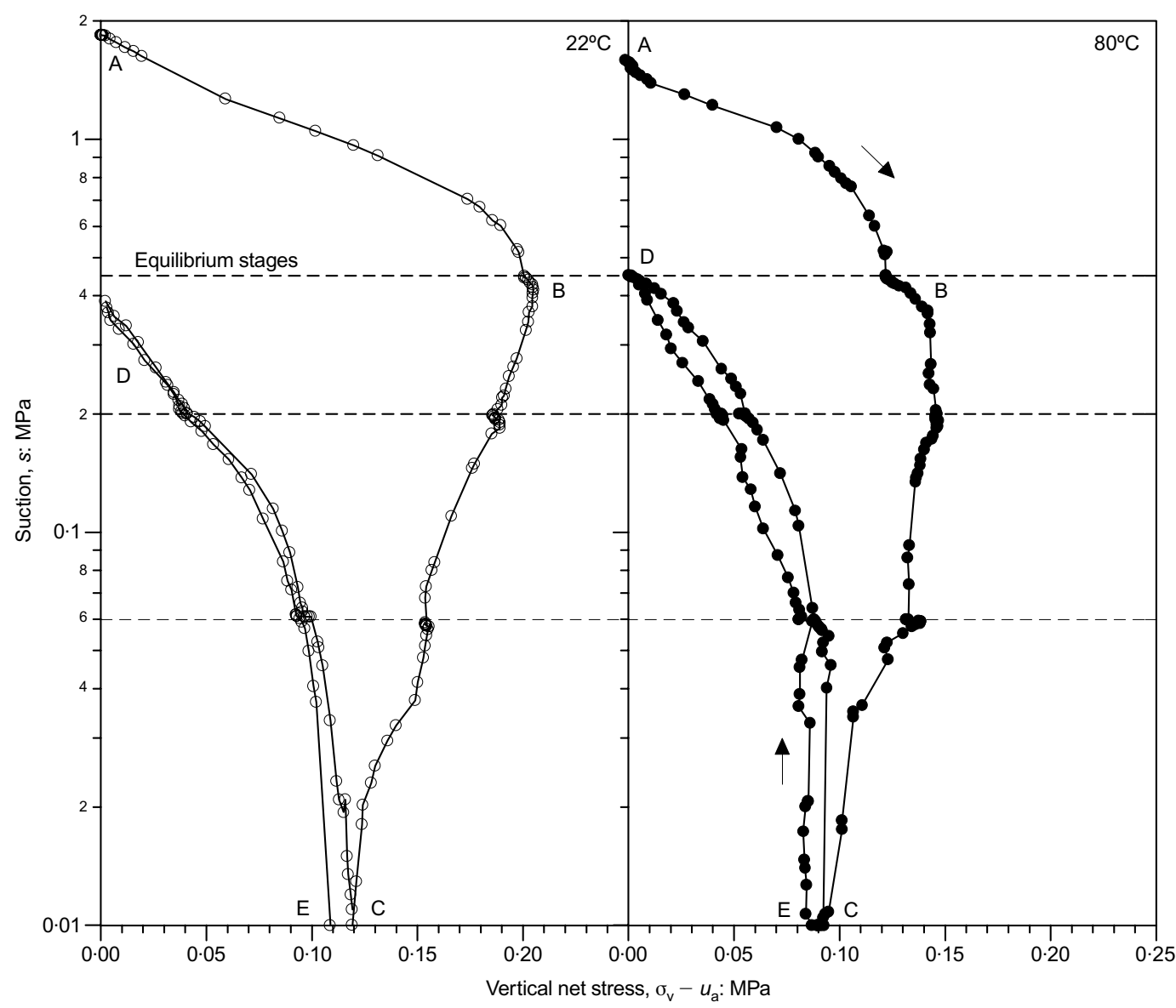

Fig. 19. Stress paths observed in swelling pressure tests (no volume change tests) performed on low-density samples $\left(\gamma_{\mathrm{d}}=13 \cdot 7 \mathrm{kN} / \mathrm{m}^{3}\right)$ at two different temperatures $\left(22^{\circ} \mathrm{C}\right.$ and $\left.80^{\circ} \mathrm{C}\right)$. The suction levels at which equilibration was allowed are indicated by horizontal dashed lines 


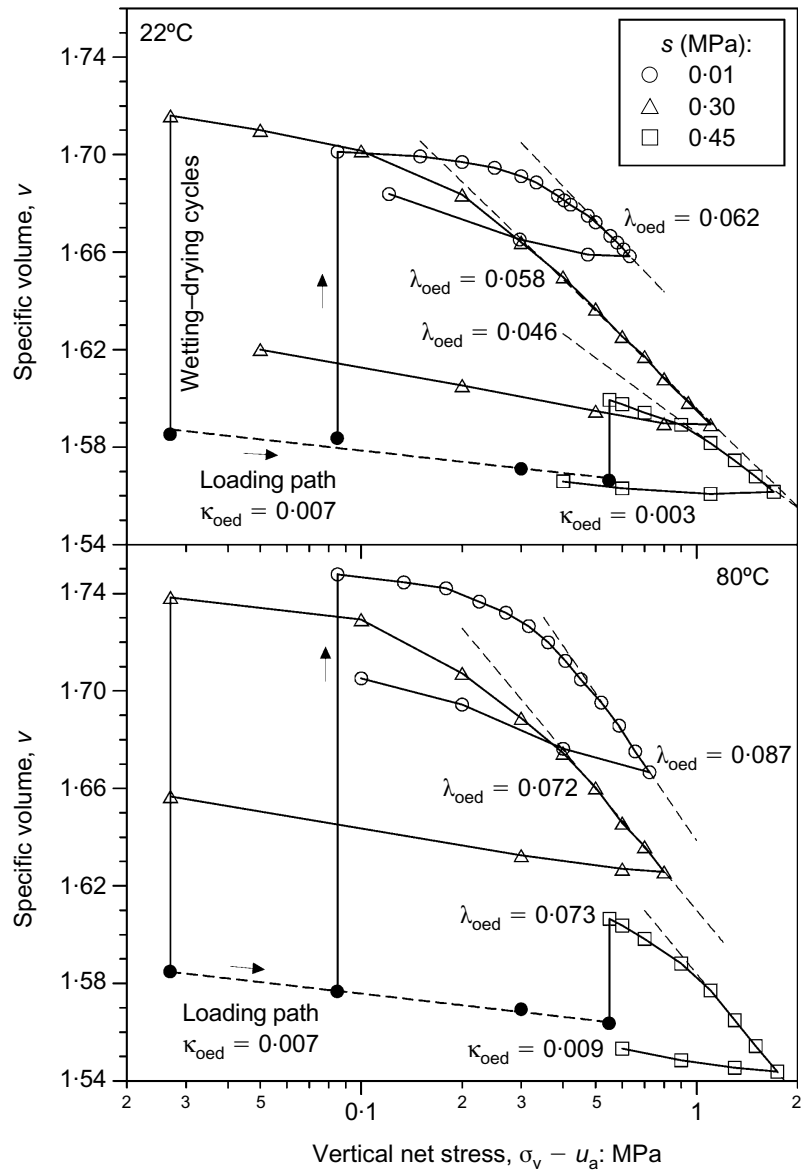

Fig. 20. Variation of specific volume, $v(1+e$, where $e$ is the void ratio), with vertical net stress for loading-unloading tests performed on high-density samples $\left(\gamma_{d}=16 \cdot 7 \mathrm{kN} / \mathrm{m}^{3}\right)$ at two different temperatures $\left(22^{\circ} \mathrm{C}\right.$ and $\left.80^{\circ} \mathrm{C}\right)$

vertical stress, suction and temperature. Two temperature levels have been selected to identify possible thermal effects: $80^{\circ} \mathrm{C}$ and $22^{\circ} \mathrm{C}$ (room temperature). High- and low-density compacted specimens of Boom clay have been tested. Examination of the test results allows a number of conclusions to be drawn regarding the mechanical behaviour of this soil under the combined effects of suction and temperature. Generally, it can be stated that the major features of unsaturated soil behaviour remain the same at the higher temperatures. However, various thermal effects can be clearly identified.

The influence of temperature on the volumetric behaviour of the soil upon wetting is variable. Swelling deformation of the high-density soil is significantly larger at the higher temperature, especially in the low-stress range. In contrast, collapse strains observed during wetting of the low-density samples appear to be unaffected by temperature. The degree of reversibility of swelling strains is also independent of temperature. Temperature also enhances shrinkage strains caused by increases of suction.

The results of non-isothermal tests on high-density samples suggest that, for this type of testing path, volumetric strains are largely path-independent. Large irreversible strains are developed during the first heating of the soil.

Temperature noticeably affects the compressibility of the soil on loading for both high- and low-density samples. This effect has been observed during the first loading of the specimens and during the loading performed after a number

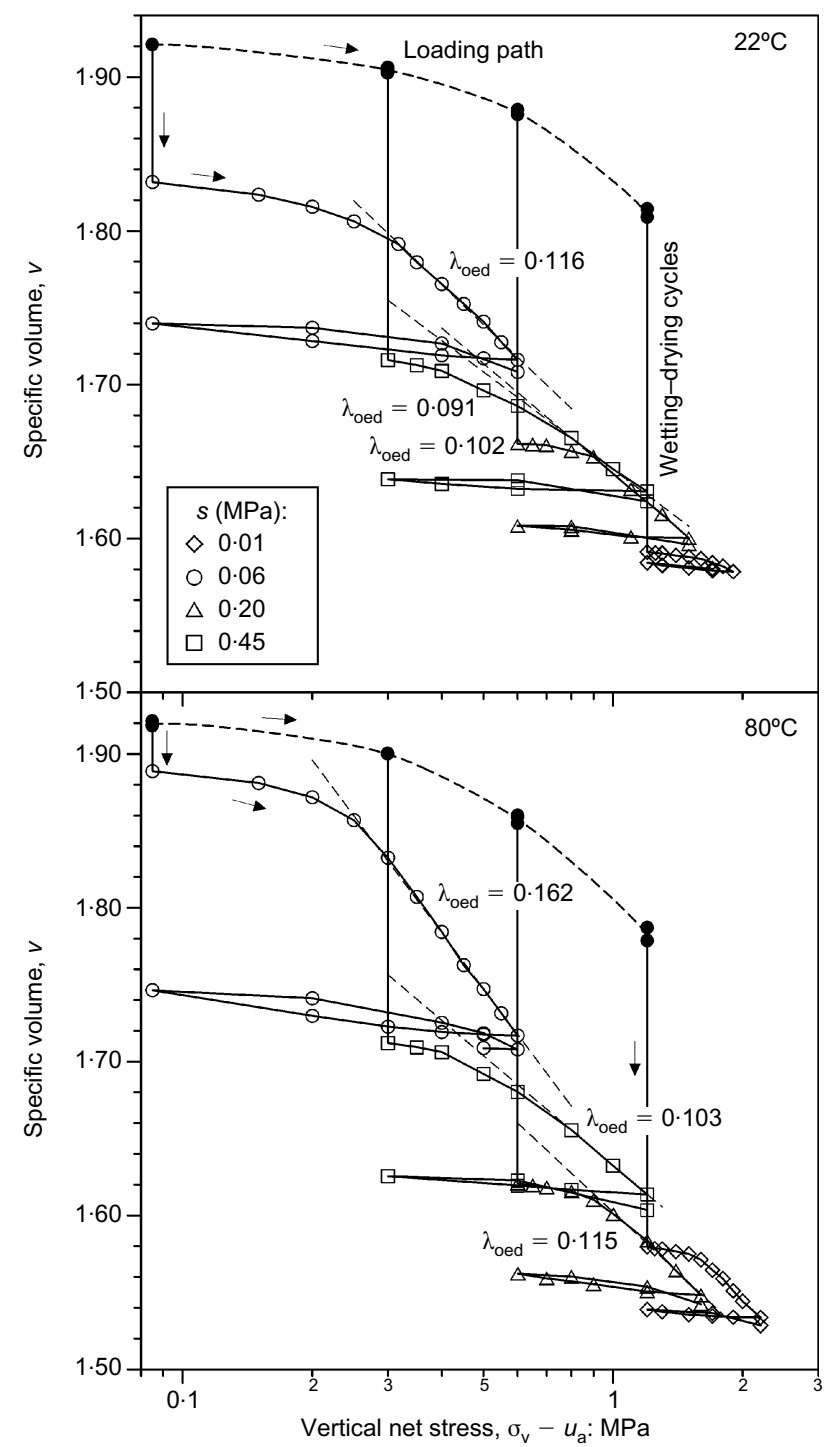

Fig. 21. Variation of specific volume, $v(1+e$, where $e$ is the void ratio), with vertical net stress for loading-unloading tests performed on low-density samples $\left(\gamma_{d}=13.7 \mathrm{kN} / \mathrm{m}^{3}\right)$ at two different temperatures $\left(22^{\circ} \mathrm{C}\right.$ and $\left.80^{\circ} \mathrm{C}\right)$

of wetting-drying cycles. In contrast, unloading stiffness seems to be independent of thermal conditions, although the compressibility values measured are quite small.

The peak stress measured in the swelling pressure test performed at high temperature is significantly smaller than that observed in the same test carried out at room temperature. This suggests that the stress domain bounded by the main yield surface reduces as temperature increases; a similar trend has often been observed in saturated soils.

\section{ACKNOWLEDGEMENTS}

The first author acknowledges the financial support provided by TDOC grant from the Comissionat per a Universitats i Recerca de la Generalitat de Catalunya. The support of the Spanish Ministry of Science and Technology through research grant BTE2001-2227 is also acknowledged. 


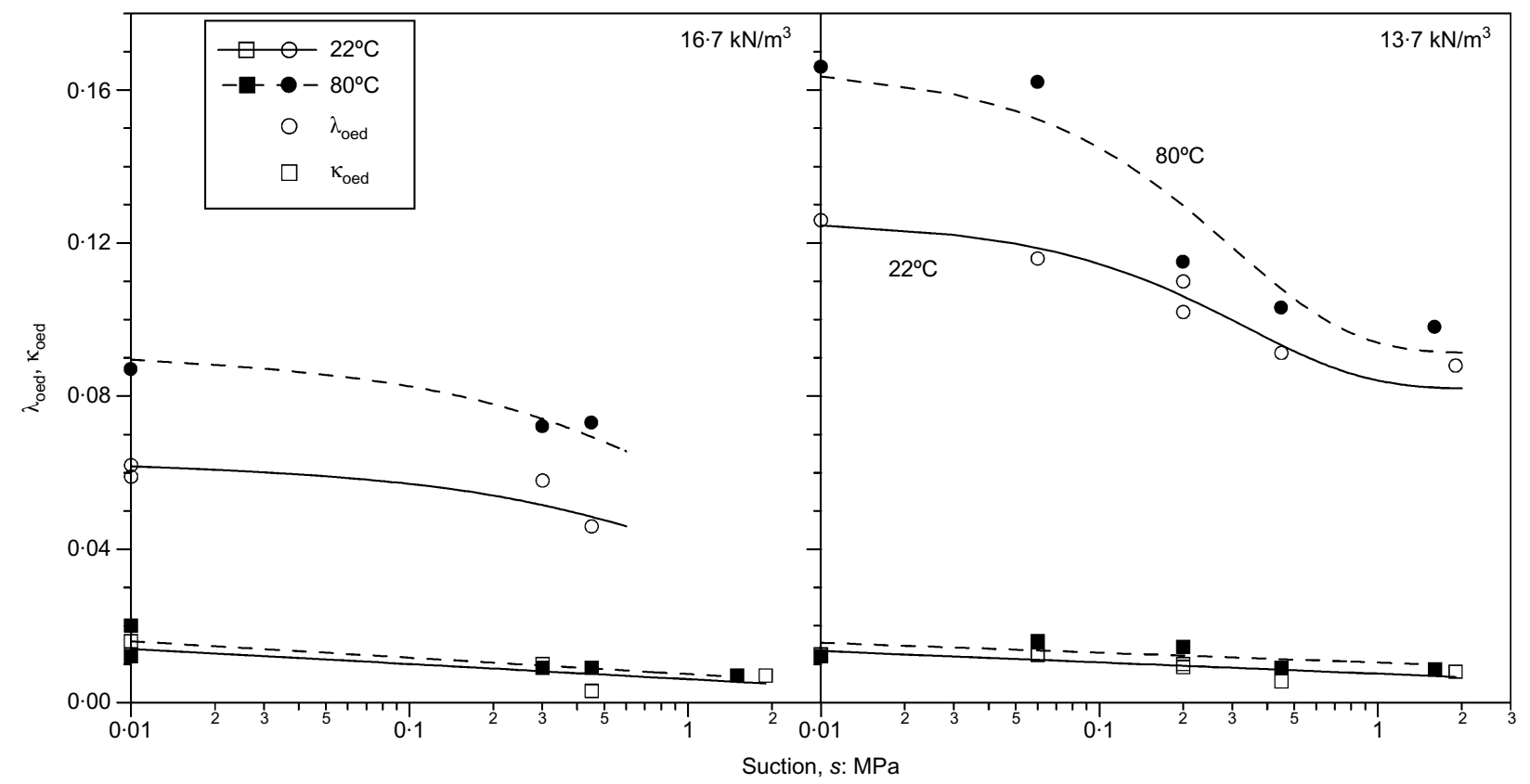

Fig. 22. Variation of pre-yield $\left(\kappa_{\text {oed }}\right)$ and post-yield $\left(\lambda_{\text {oed }}\right)$ compressibility parameters with suction for loading-unloading tests performed on high- and low-density samples $\left(\gamma_{\mathrm{d}}=16.7\right.$ and $\left.13.7 \mathrm{kN} / \mathrm{m}^{3}\right)$ at two different temperatures $\left(22^{\circ} \mathrm{C}\right.$ and $\left.80^{\circ} \mathrm{C}\right)$

\section{REFERENCES}

Akagi, H. \& Komiya, K. (1995). Constant rate of strain consolidation properties of clayey soil at high temperature. Proc. Int. Symp. on compression and consolidation of clayey soils (eds H. Yoshikuni and O. Kusakabe), 1, 3-8. Rotterdam: A. A. Balkema.

Alonso, E. E., Gens, A. \& Josa, A. (1990). A constitutive model for partially saturated soils. Géotechnique 40, No. 3, 405-430.

Alonso, E. E., Vaunat, J. \& Gens, A. (1999). Modelling the mechanical behaviour of expansive clays. Engng Geol. 54, 173-183.

Baldi, G., Hueckel, T. \& Pellegrini, R. (1988). Thermal volume changes of mineral-water system in low porosity clay soils. Can. Geotech. J. 25, 807-825.

Belanteur, N., Tacherifet, S. \& Pakzad, M. (1997). Étude des comportements mécanique, thermo-mécanique et hydro-mecànique des argiles gonflantes et non gonflantes fortement compactées. Rev. Franç. Géotech. 78, 31-50.

Burghignoli, A., Desideri, A. \& Miliziano, S. (2000). A laboratory study on the thermomechanical behaviour of clayey soils. Can. Geotech. J. 37, 764-780.

Campanella, R. G. \& Mitchell, J. R. (1968). Influence of temperature variations on soil behaviour. J. Soil Mech. Found. Div., ASCE 94, No. 3, 709-734.

Delage, P., Sultan, N. \& Cui, Y. J. (2000). On the thermal consolidation of Boom clay. Can. Geotech. J. 37, 343-354.

Eriksson, L. G. (1989). Temperature effects on consolidation properties of sulphide clays. Proc. 12th Int. Conf. Soil Mech. Found. Engng, Rio de Janeiro, 2087-2090.

Fredlund, D. G. \& Morgenstern, N. R. (1977). Stress state variables for unsaturated soils. J. Geotech. Engng. Div., ASCE 103, No. 5, 447-466.

Gens, A. (1995). Constitutive laws. In Modern issues in nonsaturated soils (eds A. Gens, P. Jouanna and B. A. Schrefler), pp. 129-158. Wien: Springer Verlag.

Gens, A. (1997). Suction and temperature, critical factors affecting soil behaviour. Proc. 14th Int. Conf. Soil Mech. Found. Engng, Hamburg 4, 2169-2171, Rotterdam: A. A. Balkema.

Gens, A. \& Alonso, E. E. (1992). A framework for the behaviour of unsaturated expansive clays. Can. Geotech. J. 29, 1013-1032.

Gens, A., García-Molina, A. J., Olivella, S., Alonso, E. E. \& Huertas, F. (1998) Analysis of a full scale in situ test simulating repository conditions. Int. J. Numer. Anal. Methods Geomech. 22, 515-548.
Graham, J., Tanaka, N., Crilly, T. \& Alfaro, M. (2001). Modified Cam-Clay modelling of temperature effects in clays. Can. Geotech. J. 38, 608-621.

Grant, S. \& Salehzadeh, A. (1996). Calculation of temperature effects on wetting coefficients of porous solids and their capillary pressure functions. Water Resour. Res. 32, No. 2, 261-270.

Horseman, S. T. \& McEwen, T. J. (1996). Thermal constraints on disposal of heat-emitting waste in argillaceous rocks. Engng Geol. 41, 5-16.

Hueckel, T. \& Baldi, G. (1990). Thermoplasticity of saturated clays: experimental constitutive study. J. Geotech. Engng Div., ASCE 116, No. 12, 1778-1796.

Hueckel, T. \& Borsetto, M. (1990). Thermoplasticity of saturated soils and shales: constitutive equations. J. Geotech. Engng Div., ASCE 116, No. 12, 1765-1777.

Kanno, T., Fujita, T., Takeuchi, S., Ishikawa, H., Hara, K. \& Nakano, M. (1999). Coupled thermo-hydro-mechanical modelling of bentonite buffer material. Int. J. Numer. Anal. Methods Geomech. 23, 1281-1307.

Lingnau, B. E., Graham, J. \& Tanaka, N. (1995). Isothermal modelling of sand-bentonite mixtures at elevated temperatures. Can. Geotech. J. 32, 78-88.

Lingnau, B. E., Graham, J., Yarechewski, D., Tanaka, N. \& Gray, M. N. (1996). Effects of temperature on strength and compressibility of sand-bentonite buffer. Engng Geol. 41, 103-115.

Ma, C. \& Hueckel, T. (1992). Stress and pore pressure in saturated clay subjected to heat from radioactive waste: a numerical simulation. Can. Geotech. J. 29, 1087-1094.

Ma, C. \& Hueckel, T. (1993). Thermomechanical effects on absorbed water in clays around a heat source. Int. J. Numer. Anal. Methods Geomech. 17, 175-196.

Mitchell, J. K. (1993). Fundamentals of soil behaviour, 2nd edn. New York: John Wiley.

Morin, R. \& Silva, A. J. (1984). The effects of high pressure and high temperature on some physical properties of ocean sediments. J. Geophys. Res. 89, No. B1, 511-526.

Plum, R. L. \& Esrig, M. I. (1969). Some temperature effects on soil compressibility and pore water pressure. Highway Research Board, Special Report 103, pp. 231-242.

Recordon, E. (1993). Déformabilité des sols non saturés à diverses températures. Rev. Franç. Géotech. 65, 37-56.

Robinet, J. C., Pasquiou, A., Jullien, A., Belanteur, N. \& Plas, F. (1997). Expériences de laboratoire sur le comportement thermo- 
hydro-mécanique de matériaux argileux remaniés gonflants et non gonflants. Rev. Franç. Géotech. 81, 53-80.

Romero, E. (1999). Characterisation and thermo-hydro-mechanical behaviour of unsaturated Boom clay: an experimental study. $\mathrm{PhD}$ thesis, Universitat Politècnica de Catalunya.

Romero, E., Lloret, A. \& Gens, A. (1995). Development of a new suction and temperature controlled oedometer cell. Proc. 1st Int. Conf. on Unsaturated Soils, Paris 2, 553-559, Rotterdam: A. A. Balkema/Presses de L'Ecole Nationale des Ports et Chaussées.

Romero, E., Gens, A. \& Lloret, A. (2000). Temperature effects on water retention and water permeability of an unsaturated clay. Proc. of Asian conference on unsaturated soils, Singapore, pp. 433-438. Rotterdam: A. A. Balkema.

Romero, E., Gens, A. \& Lloret, A. (2001a). Laboratory testing of unsaturated soils under simultaneous suction and temperature control. Proc. 15th Int. Conf. Soil Mech. Geotech. Engng, Istambul 1, 619-622, Liss: A. A. Balkema/Swers \& Zeitlinger B. V.

Romero, E., Gens, A. \& Lloret, A. (2001b). Temperature effects on the hydraulic behaviour of an unsaturated clay. Geotech. Geol. Engng 19, 311-332.

Saix, C. (1991). Consolidation thermique par chaleur d'un sol non saturé. Can. Geotech. J. 28, 42-50.

Saix, C. \& Jouanna, P. (1990). Appareil triaxial pour l'étude du comportement thermique de sols non saturés. Can. Geotech. J. 27, 119-128.
Saiyouri, N., Hicher, P. Y. \& Tessier, D. (1998). Microstructural analysis of highly compacted clay swelling. Proc. 2nd Int. Conf. on Unsaturated Soils, Beijing 1, 119-124, Beijing: International Academic Publishers.

She, H. Y. \& Sleep, B. E. (1998). The effect of temperature on capillary pressure-saturation relationships for air-water and perchloroethylene-water systems. Water Resour. Res. 34, No. 10, $2587-2597$.

Sherif, M. A., Ishibashi, I. \& Medhin, B. W. (1982). Swell of Wyoming montmorillonite and sand mixtures. J. Geotech. Engng Div., ASCE 108, 33-45.

Tanaka, N., Graham, J. \& Crilly, T. (1997). Stress-strain behaviour of reconstituted illitic clay at different temperatures. Engng Geol. 47, 339-350.

Tidfors, M. \& Sällfors, G. (1989). Temperature effect on preconsolidation pressure. Geotech. Test. J. 12, No. 1, 93-97.

Towhata, I., Kuntiwattanakul, P., Seko, I. \& Ohishi, K. (1993). Volume change of clays induced by heating as observed in consolidation tests. Soils Found. 33, No. 4, 170-183.

Towhata, I., Kuntiwattanakul, P., Seko, I. \& Ohishi, K. (1995). Closure of discussion. Soils Found. 35, No. 3, 124-127.

Wiebe, B., Graham, J., Tang, G. X. \& Dixon, D. (1998). Influence of pressure, saturation and temperature on the behaviour of unsaturated sand-bentonite. Can. Geotech. J. 35, 194-205.

Zhang, F., Zhang, Z. Z., Low, P. F. \& Roth, C. B. (1993). The effect of temperature on the swelling of montmorillonite. Clay Miner. 28, 25-31. 